\title{
Private Domestic Investment and Manufacturing Sector Output in Nigeria
}

\author{
Lawrence Oghenemaro Ebelebe ${ }^{1}$, Chukwuemeka Amaefule ${ }^{1^{\star}}$
}

\author{
${ }^{1}$ University of Port Harcourt, NIGERIA \\ *Corresponding Author: chukwuemekamaefule@gmail.com
}

Citation: Ebelebe, L. O. and Amaefule, C. (2020). Private Domestic Investment and Manufacturing Sector Output in Nigeria. European Journal of Sustainable Development Research, 4(4), em0140. https://doi.org/10.29333/ejosdr/8479

\section{ARTICLE INFO}

Received: 4 May 2020

Accepted: 23 Jul. 2020

\begin{abstract}
This study examined the impact of private domestic investment on manufacturing sector output in Nigeria from 1970 to 2017. The study specifically looked at the impact of private domestic investment on manufacturing sector's output in a static and dynamic model. Six variables were employed in the study and were sourced from CBN statistical bulletin and World Development Indicators for the period covering from 1970 to 2017. The analysis of the variables undergoes three approaches, the pre-analysis of data, model estimation and the diagnostic analysis of the model. The first approach employed tables and graphs to explain the behaviour of the data, equally the univariate analysis of the data were examine with the Augmented Dickey-Fuller equations and the possibility of long-term relationship. The models were estimated with the ARDL estimator and model selected with the Akaike Information Criteria, and finally the models estimated were tested using the Jaque-Bera statistics, Ramsey RESET Test, Breusch-Godfrey and Harvey test for residual normality, specification bias, autocorrelation and heteroskedasticity respectively. The results from the analytical methods shows that there is over 82 percent increase in the output of Manufacturing sector in the late 1970s and early 1980s and over 98 percent increase the output of the manufacturing sector in the late within 2010 and 2015. Also, the study observed that the responses of output of the manufacturing sector to private domestic investment are positive and significant in the static and dynamic models. The study found that the impact of private domestic investment on manufacturing sector output were fairly elastic in the static model and fairly inelastic in the dynamic model. Finally, the study found that the model have a weak adjustment mechanism. The adjustment of disequilibrium between static and dynamic equilibrium is weak or just 24.9 percent. Since private domestic investment is significant and positively impacted on the performance of the manufacturing sector irrespective of the time zone, the study recommended for increase in the credit to private sector by the apex monetary authority.
\end{abstract}

Keywords: private domestic investment, manufacturing sector output, ARDL

\section{INTRODUCTION}

Investment is a positive determinant in the Keynesian macroeconomic framework. The debate between investment and economic growth in developing economies seemed to be silent at sector disaggregated levels. Notably among the sectors is the manufacturing sub-set of the industrial sector. Regrettably, the manufacturing sub-sector of Nigeria is still bordered with its low output performance as its share to Gross Domestic Product volume is still low and has a minimal significant in causing growth in the Nigerian economy. This calls for concern for the fiscal managers and policymakers even as the country's quest to becoming one of the leading economies of the world comes 2020.

Chronicling the outcome and overall performance of this sector as noted and submitted by Ade-Agoye (2011) the share contribution of the manufacturing sector to GDP growth dropped significantly from 15 percent in the period of 1970 s to $4.21 \%$ in 2010. The poor and limited outcome resulted in the shutdown of over 1000 manufacturing companies nationwide. Besides, the central bank of Nigeria in the year 2005 complained and insisted that the manufacturing sector witness an on unimpressive growth. Omankhanlen and Owonibi (2012) noticed on average that the manufacturing sector is strictly riddled with a lot of multifarious issues. Outside infrastructure, there are other problems such as the suffocating of the high rate of interest and other issues like bank's reluctance to loan to this (industrial) sector even with the specification of the monetary authorities to do so as the authorities classify see it as a priority sector. The contribution of this sector's output to GDP growth rate, from the observation of the negative economic indicators point, stood at the value of 4.23 percent in 2013. In the recent record, the sector's outputs have experienced sharp declines due largely to factors like unfavourable exchange rates, the economic recession in 2016, poor facilities of infrastructure among other negative factors of growth (Yasmin, 2018). 
Given the global imperativeness of the private investment contribution to growth, it is germane to fashion and develop researches that critically examine the effect of the private domestic investment on the manufacturing sub-sector. It is on this notice and backdrop that prompted us to investigate the impact of private domestic investment on the manufacturing output performance considering the Nigerian economy.

Thus, the question motivating this research becomes what is the impact of private domestic investment on manufacturing sub-sector in Nigeria? Does the private domestic investment have a cointegrating relationship with the Nigerian manufacturing sector output performance? Thus, the focus of this study is therefore to; conduct trend analysis on private domestic investments, manufacturing sector output, and other hypothesized variables; and determine the dynamic relationship between private domestic investment and manufacturing sector's output in Nigeria.

\section{LITERATURE REVIEW}

\section{Theoretical Framework}

Accelerator principle model insisted on the point that a rise in the output rate tend to lead to a corresponding rise in the capital stock. Capital stock simply defines the desire level of capital stock, $K^{*}$. Tracing the capital-output nexus equates fixed static v; the desired level of the capital stock is constant proportion to output so that in any time $t$, the following is anticipated

$K_{t}^{*}=v Y_{t}$ where the left hand side of the equation is the optimum capital stock in time $t$ and

$\mathrm{v}$ is the accelerator and is positive and $\mathrm{Y}_{\mathrm{t}}$ is the total output in time $t$. Thus, the outcome anticipated from the relationship means that any alteration in the output will affect the existing capital stock. Hence;

$$
\begin{gathered}
K_{t-1}^{*}=v\left(Y_{t}-Y_{t-1}\right) ; \text { and } \\
I_{n t}=v\left(Y_{t}-Y_{t-1}\right) ; \text { therefore; } \\
I_{n t}=K_{t}^{*}-K_{t-1}^{*}=v \Delta Y_{t}
\end{gathered}
$$

$\therefore \Delta Y_{t}=\left(Y_{t}-Y_{t-1}\right)$; and $I_{n t}$ is the net investment.

Where $K_{t-1}^{*}=$ lagged capital stock, $I_{n t}=$ net investment at time t, $\Delta Y_{t}=$ Output change at time $\mathrm{t}$

The above equation stated showed the proportional relationship between the levels of net investments to that of outputs level.

Although, the modern in the accelerator equation was developed by Clark (1917), the original idea can be traced to the analysis of the Aftalian in 1911. Accelerator model can be singled from the Neoclassical capital theory if we assume a constant return to scale production function. Given constant return to scale optimal (least cost) the capital labor ratio is factored out by the cost of capital in relation to the cost of labor and is invariant, in respect to change in output, if additional capital and labor costs are static, then both factors are expanded proportionately when planned output rise. This means that the total level of capital-output ratio; $v$ remains unchanged as output expands. The level and desired capita; $K^{*}$ is therefore unchanged as output expands i.e. $K^{*}=v Y$.

The fixed relationship between the desired stock of capital and the planned level of the output can be alternatively derived by making non-neoclassical assumption that labour and capital cannot be substituted for each other. For easy grasp, the accelerator relationship is assumed as linear involving an incremental optimal capital-output ratio $\frac{d k}{d Q}$, which indicates how many additional capitals are required by profit maximizing firms to produce extra unit of products (see Anyanwu, 1997; Jhingan, 2008; Onuchuku et al., 1998).

Adopting flexible accelerator principle, the model states that an equilibrium or a certain amount of capital stock is required to or boost increase a certain level of output of a firm given its technology, interest rates, etc (Gujarati, 1999). Assuming the desired rate of capital $Y^{*}$ is a linear function of $X$ (output) in this manner

$$
\text { Given, } Y_{t}^{*}=\beta_{0}+\beta_{1} X_{t}+\mu_{t}
$$

Since the desired rate of capital is indirectly observable.

Nerlove postulates the thus hypothesis is referred as the partial adjustment mechanism

$$
Y_{t}-Y_{t-1}=v\left(Y_{t}^{*}-Y_{t-1}\right)
$$

Where $\delta$ is known as coefficient of adjustment, such that $0<v \leq 1$ (Probability condition for transformation to occur).

$$
Y_{t}=v Y_{t}^{*}+(1-v) Y_{t-1}
$$

From eq. $4 ; Y_{t}^{*}=\beta_{0}+\beta_{1} X_{t}+\mu_{t}$ substitute 4 into eq. 6

$Y_{t}=v\left(\beta_{0}+\beta_{1} X_{t}+\mu_{t}\right)+(1-v) Y_{t-1} ;$ multiply by $v$

$$
Y_{t}=v \beta_{0}+v \beta_{1} X_{t}+(1-v) Y_{t-1}+v \mu_{t}
$$

Where $Y^{*}=$ desired level of capital, $Y_{t}=$ output at a particular time $t$

The above model as in (7) is the Marc Nerlove partial adjustment method which highlights the transformation flexibility in a distributed lag equation to become an autoregressive. Hence, our model for this study will be built around the Marc Nerlove partial adjustment method and hence the model employed in this study assumed an autoregressive form. 


\section{Empirical Literature}

Oyedokun and Ajose (2018) in examining and understanding the vital link between domestic private businesses and Nigerian economic progress by employing the causality granger test and Vector ECM model from 1980-2016. The outcome of their analysis revealed that a long run significant relationship exists with domestic private business granger causing the growth of the real GDP at all levels.

Odufuye (2017) showed with the OLS technique of equation estimate that commercial bank credits to the small and medium scale businesses, credit to the private sector, interest rates dynamism and broad money supply insignificantly impacted on the real sector performance in Nigerian within the time of 1990 to 2015.

Okoye (2017) argued specifically that bank sector consolidation impacted on the banking sector performance positively with a feedback impact on the real sector. Bada, (2017) used data between the specified period of 1984 and 2014 and the analysis showed that there is a relationship between bank credits and the performance of the real sector in Nigeria. He noticed that credits from banks have significantly impacted on the output of the manufacturing and agricultural sector within a VAR framework.

Ume et al. (2017) examine the role of bank loans and advances to the performances of the manufacturing sector output from the period of 1986 to 2013. The nature of the time series data led them to adopt the Auto-Regressive Distributional Lag equation to evaluate the short and long-run impact of the credits from banks to the outputs of the manufacturing sector in Nigeria. The indicated result revealed that the ratio of the credit to the private sector to GDP, interest rate movements, banks' credits volume impacted significantly on the output of the manufacturing sector. The work also indicated that the effect of rates of exchange on the output of the manufacturing sector was insignificant and it will take on average at least three periods for the disequilibrium to be corrected from the static period to the dynamic period balance.

John and Terhemba (2016) used the Cochrane-Orcutt model to estimate the total effect of the commercial bank's credit rate on the output of the manufacturing sector of Nigeria between the time of 1980 and 2015. He tested group and serial behavior of the series or data with the equation of Dickey-Fuller. The Cochrane-Orcutt technique reveals an inverse impact of inflation and interest rates on the manufacturing sector output in Nigeria.

Whereas the volume of money supply and that of the loans and advances of the banks have a total positive behaviour to the manufacturing sector output.

With a special arrangement of data between the time of 1981 and 2013, Anetor et al. (2016) researched the impact of bank credit on the development of the agricultural sector in Nigeria. The authors applied the VAR framework to analyze the information on their model and they, therefore, discovered that agricultural credit guarantee scheme funds affected the output of the agricultural sector insignificantly, whereas the impact of loans and advances of deposit money banks in the study was significant.

Sogules and Nkoro (2016) observed with keen interest the role of bank credits and the performance of the real sector in the Nigerian economy from the time frame of 1970 and 2013.they specifically noticed the effect of banks' credit facilities on the agricultural and manufacturing sector performance in Nigeria. The pre-test results from the study showed that possible long-run direction or relationship exists among the included variables in their equation. They noticed and therefore stated that the relationships that exist between banks' credit and the activities of the agricultural and manufacturing are purely insignificant.

Obamuyi, Edun, and Kayode (2016) intensively researched the role of the banks' lending, growth of the economy, and basically the performance of the manufacturing sector of the Nigerian economy. The authors applied the yearly time series data sourced from the central bank of Nigeria statistical bulletin, for 36 years. The multivariate techniques of VECM were used after checking the unit-roots outcome and the co-integrating link exists among the series and behavior of the data in the model. They used banks' credit rate, index of the manufacturing production, manufacturing capacity utilization, financial deepening, inflation rate, maximum rates of lending, and the exchange rate value in the multivariate framework. They noticed initially that from the study, banks' lending rates and manufacturing capacity utilization affected manufacturing sector output significantly in Nigeria, but noticed an insignificant possibility between manufacturing sector performance and the model of the economic growth.

Ajudua and Davis (2016) used data from 1986 to 2014 to estimate the factors that influence the activities of the manufacturing sector performance in Nigeria. They listed Bank credit to the sector, gross employed labour force, capital formation, lending rate, manufacturing sector capacity utilization, rates of exchange, and foreign investment as the major determinants of the manufacturing sector performance. Their study indicates that all the series have significantly impacted on the performance of this very sector.

Kalu and Mgbemena (2015) applied ECM to attempt a link between private local investment and the rate of economic growth in Nigeria with the application of the Cobb-Douglas model framework. The analysis revealed a significant relationship between domestic private investment and economic growth.

Chinweoke, Egwu, and Elizabeth (2015) specifically examine the real effect of deposit money loans and advances on the performances of the real sector output with Nigerian data from 1994 to 2013 . He proxied the real sector to include the activities of the manufacturing and agricultural sectors. They obtained these relevant and necessary data from the official website of the central bank of Nigeria statistical bulletin of 2013 and they subjected the data to the OLS technique of regression analysis. They significantly noticed that the causal relationship among banks' loans and advances and the real sector (manufacturing and agricultural sectors) performance in Nigeria.

Korkmaz (2015) in a special panel analysis, model an equation to examine the bank credit effect on the growth of the economy and inflation level in 10 countries of Europe. He uses the model of Levin-Lin-Chu and the PP-Fisher Chi-Square method was adopted to check the unit root of the data used in the analysis or Panel framework. The accepted fixed impact model showed that 
on average a highly significant link exists between bank credit and economic growth whereas an insignificant relationship between domestic private credit and inflation exists in the model within the period of the study.

The analysis carried out by Ogar, Nkamare, and Effiong (2014) used the Ordinary Least Square estimator to examine the data from the central bank of Nigerian statistical bulletin to observe and understand the banks' credit impact on the manufacturing sector activities within the time frame of 1992 to 2011. They significantly noticed from their model that output of the manufacturing sector, banks' credit, and interest rate. Also, from the study, it was observed that the used series in the model are stationary at level form thus there was no point in conducting the pre-information on the movement or behavior of the series in the model. On the outcome, the result revealed that the commercial banks' credits significantly impacted the manufacturing output performance on the average within the period reviewed.

With the special case of application of the error correction model by Oni, Akinlo, and Oladepo (2014) reveals that both the two periods (short and long-run economic analysis) that banks' credit to the agricultural and the manufacturing sectors is significant and positive indicating the direction of the real sector. Their model also revealed that the impacts of rates of exchange and inflation on the performance of the two most recognized real sectors were negative from the gathered time-series data from 1980 to 2010 .

Nwakanma, Nnamdi, and Omojefe (2014) demonstrated with the application of the ARDL equation that there is a possible and significant dynamic relationship between bank credit to the activities of the private sector and growth of the Nigerian economy but an opposite direction exists between the causality of the variables.

Mamman and Hashim (2013) analyzes the relationship between private sector credit received and the real sector activities in the Nigerian economic system from the time of 1986 to 2010. They used data from the statistical bulletin of the official website of the Central Bank of Nigeria and their study revealed that there is a special relationship between the private sector credits and the performance of the real sector in Nigeria. They pointed out that the extent of the relationships positive with the ordinary least square techniques of regression method.

Obilor (2013) researched the financial credit sector impact on the growth and development of the agricultural sector of Nigeria within the periods of 24 years. They work intensively to examine the impacts of commercial bank's credit to agriculture, agricultural guarantee scheme fund, government fund allocation, and agricultural output pricing on agricultural product output index. The simple OLS results expose that bank's credit to the agricultural sector and agricultural sector guarantee scheme fund impacted on agricultural product output index positively and is significant from both analysis of the short and long-run periods of adjustment in the model. Furthermore, the work indicated that the government's financial allocation to the agricultural sector and agricultural product pricing was a positive and significant impact on the agricultural output index.

Oluitan (2012) studied the causal relationship between bank credits and growth in a VAR framework from 1970 to 2005 . The work revealed a causal relationship between economic growth and bank credits but points out that the causality runs from bank credits to economic growths in Nigeria.

Anthony (2012) employed total domestic private savings as the percentage of the growth rate of the economy, GDP per capita, the real level of an interest rate of financial deepening, rate of interest spread and inflation rate in a Distributional Lag-Error Correction model to evaluate the real impact of the bank saving and bank credits on economic growths in Nigeria. The revealed outcome from the Distributional Lag-Error Correction techniques indicates that the rate of financial deepening, interest rate spread and GDP capita impacted economic growth positively, while the rate of real interest and inflation rates impacted growth negatively. Also, the previous year's private domestic saving to GDP, the previous year's private sector credit, the previous year public sector credits, and the previous year rate of interest and the rate of exchange as well as impacted on growth positively in Nigeria.

Akpansung and Babalola (2011) applied data sourced the yearly central bank of Nigeria statistical bulletin to ascertain the nexus and direction between banking sector credits and economic growths in Nigeria from the period ranged between 1970and 2008. They employed the VAR framework by Granger to examine the direction of causalities from the variables or series included in the analysis and they used the Two-Stage least Square estimators to modeled the empirical direction of the variables included in the study. The a theoretical analysis reveals unidirectional causal effects flowing from growth to private sector credits and causality from the industrial sector to economic growth. While the empirical outcomes reveal that privates sector credits impacted positively on the rate of economic progress whereas lending rates negate economic growth in the Nigerian environment from the reviewed periods.

\section{MODEL SPECIFICATION}

The model specification was got from the flexible accelerator model. From equation 2.7 in the foregoing chapter, an autoregressive scheme under Marc Nerlove adjustment mechanism was defined. Hence, the study equation will be built from the listed assumption by taking into effect lag adjustment framework of investment. Thus, we employed Bound testing ARDL approach.

The study will adopt secondary data collection method. This source of data collection synergizes with quasi experimental design. In this regards, data from Central Bank of Nigeria Statistical bulletin, World Development Indicators (WDI) on various issues will be consulted to obtained data for the various variables under consideration. 
Quasi experimental design method is defined as an empirical interventional study employed to estimate the causal impact of an intervention on target population without any random assignment. The initial stage of employing quasi experimental design is to identify the variables. Thus, in equation 8 we defined the variables into dependent and independent variables. They are viz;

$$
M S Q=\beta_{0}+\beta_{1} P D I+\beta_{2} R L R+\beta_{3} I N F T S+\beta_{4} I N F+\beta_{5} E X R+\beta_{6} M S Q t-1+V
$$

Where;

$$
\begin{aligned}
& \text { apriori expectation; } \beta_{1}>0 ; \beta_{2}<0 ; \beta_{3}>0 ; \beta_{4}>0 ; \beta_{5}>0, \beta_{6}>0 \text { are the intercepts } \\
& \text { MSQ = Manufacturing Sector Output } \\
& \mathrm{PDI} \quad=\text { Private Domestic Investment } \\
& \text { RLR = Real Lending Rate } \\
& \text { INFTS = Level of Investment in Infrastructure } \\
& \text { EXR = Exchange Rate } \\
& \text { INF = Inflation Rate } \\
& \mathrm{MSQ}_{\mathrm{t}-1}=\text { lag Manufacturing Sector Output } \\
& \mathrm{V}=\text { = Stochastic Term }
\end{aligned}
$$

The nexus between accelerator principle and ARDL is rest squarely on the nature on the influence of lag on investment decision of investors.

\section{Analytical Framework}

ARDL is primarily employed to estimate the time definition of PDI in a dynamical system, taking into account the lag effect of investment behaviour and its impact on manufacturing sector output. Investment behaviour is made up of two phases as captured in the flexible accelerator principle. Thus, it is base on the ARDL framework our empirical model is built. Thus model 9-11 follows the lag structure in ARDL. ECM is used to investigate, reconcile, measure the time variation of adjustment that occurs with the hypothesized variables. ECM empirically decomposes the impact of PDI on MSQ into short-run dynamics and long-run dynamics.

In an attempt to find the long-run impact between private domestic investments on the manufacturing sector. The study used the error correction mechanism and the cointegration approach

$$
\begin{gathered}
\Delta Y_{1}=\alpha Y_{t-1}+\sum_{t=1}^{m} B \Delta Y_{t-1}+\delta+Y_{t}+\varepsilon_{t} \text { (For levels) } \\
\Delta \Delta Y_{t}=\alpha \Delta Y_{t-1}+\sum_{t=1}^{m} B \Delta \Delta Y_{t-1}+\delta+Y_{t}+\varepsilon_{t} \text { (For first difference) }
\end{gathered}
$$

Where;

$\Delta Y$ stands for the first difference of the series and its number of lags and the value of $t$ stand for time

\section{Error Correction Model}

$$
\Delta Y_{t}=\alpha_{0}+\alpha_{1} \Delta X_{t}+\alpha_{2} U_{t-1}+\varepsilon_{t}
$$

Where; $\alpha_{i}$ to $\mathrm{a}_{2}$ is the adjustment degree

Co-integration and Error Correction Mechanism (ECM) are applied to establish the real point of the long-run link in the model. This is because most time-series data that exhibit strong trends are non-stationary (Gujarati, 2004).

Usually, the testing and analysis of the test (unit root) lead to the theoretical assumption of co-integration (Ekanem, 2002). Cointegration according to Granger (1981), and Engel and Granger (1987) corrects the issue of integrating short-run dynamics with long-run equilibrium. Specifically, the theory demonstrates that if two or more variables are co-integrated, it, therefore, means that there is a meaningful long-run impact between the series. The short-run dynamics can be analyzed from the ECM.

Economic series is said to be integrated of order-zero, that is $I(0)$ if the initial time series is stationary. Those that are differenced once to obtain stationarity are said to be integrated of order-one, that is $/(1)$. There are series that have to be differenced more than once to become stationary.

\section{Trend Analyses}

Table 1 revealed the average values of the six included series in the work. The averages were considered within five annual exceptions of 2015 to 2017 that are considered 3 annuals. There are two critical periods shown in the above data, the movement from 1979 to the average of 1980 to 1984 and the movement from 2009 to the average of 2010-2014. The figure for the manufacturing sector output grows with over $82 \%$ in the early 1970 s and 1980 s and with over $98 \%$ between 2009 and the average period of 2010-2014. The tremendous enhancement in the manufacturing sector output in the late 1970s and early 1980 s can be attributed to the domestic policy of trade substation strategy whereas the recent improvement within the period 2009,2010 to 2017 can be attributed to the statistical changes in the analysis of GDP in the country. 


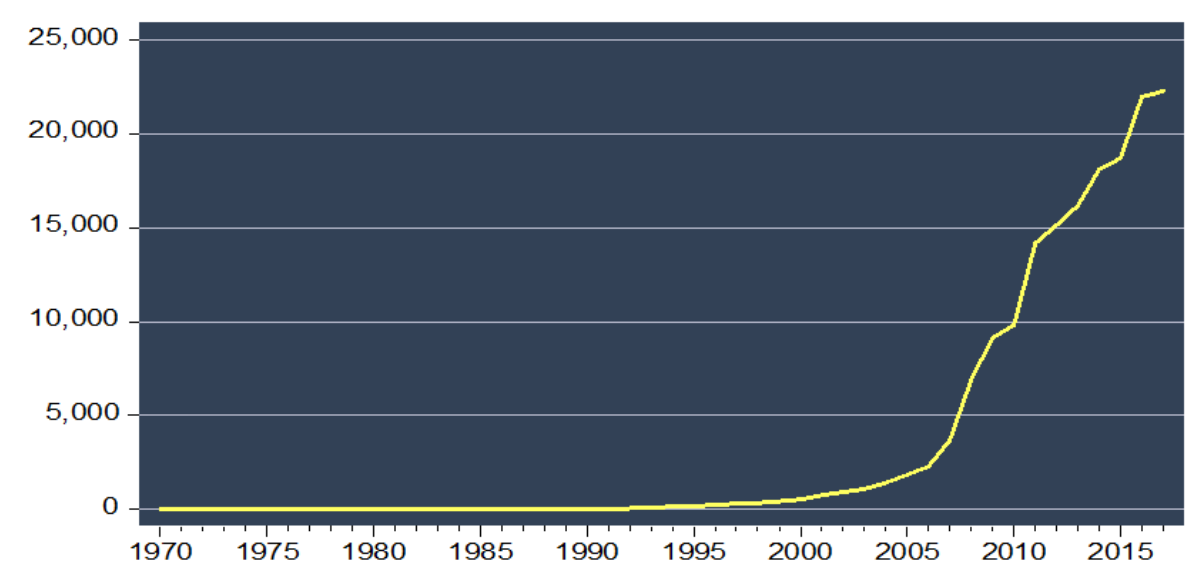

Figure 1. Graph of Private Domestic Investment in Nigeria, 1970-2017

Source: E-views 9

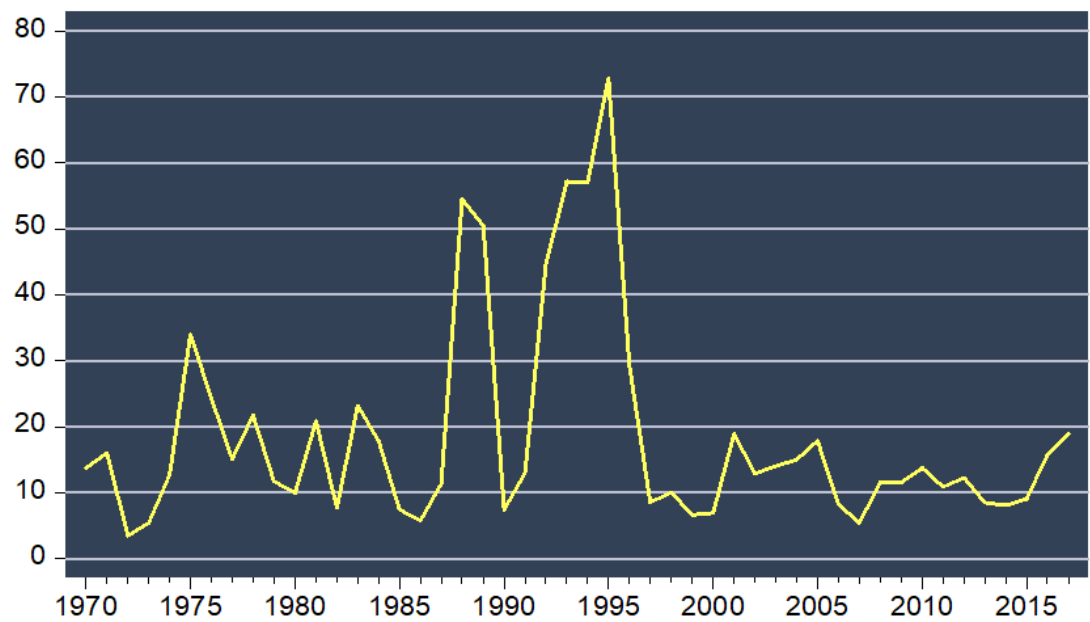

Figure 2. Graph of Inflation Rates in Nigeria, 1970-2017 Source: E-views 9

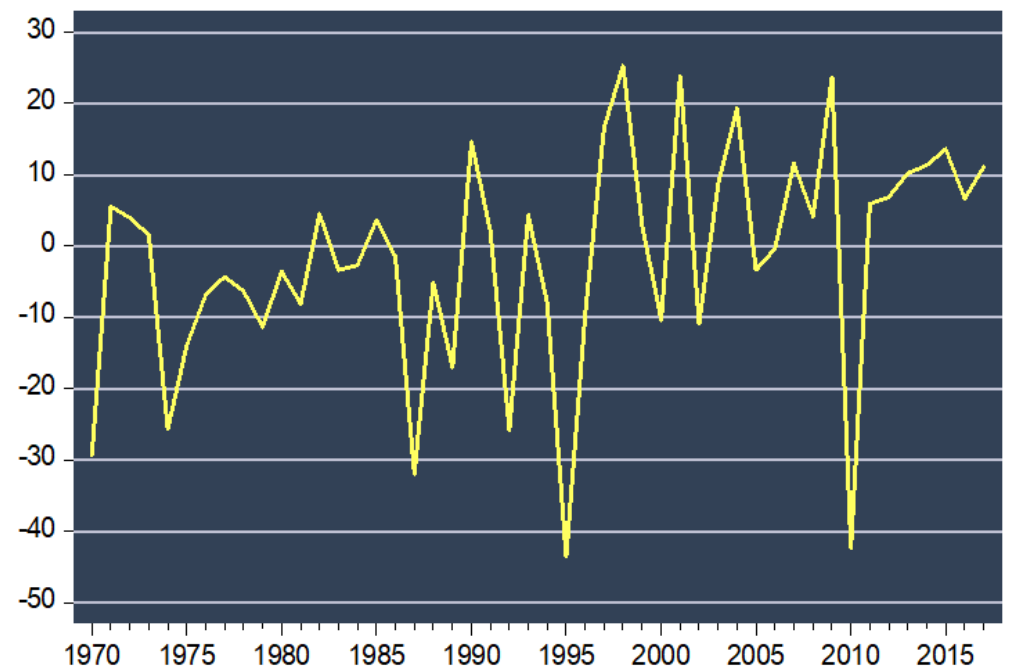

Figure 3. Graph Real Lending Rates in Nigeria, 1970-2017

Source: E-views 9 


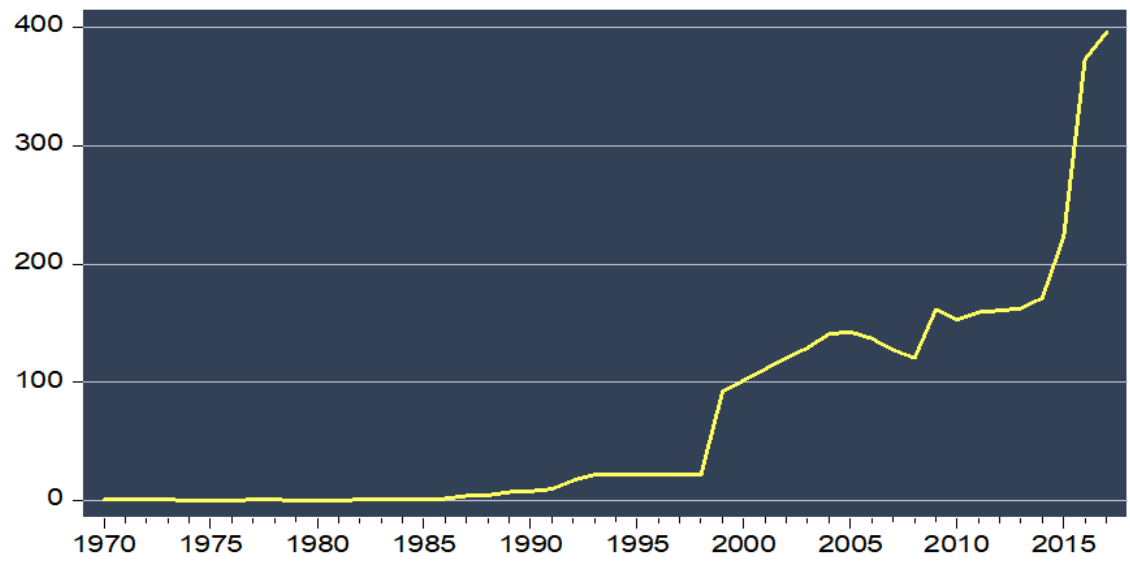

Figure 4. Graph of Foreign Exchange Rates in Nigeria, 1970-2017

Source: E-views 9

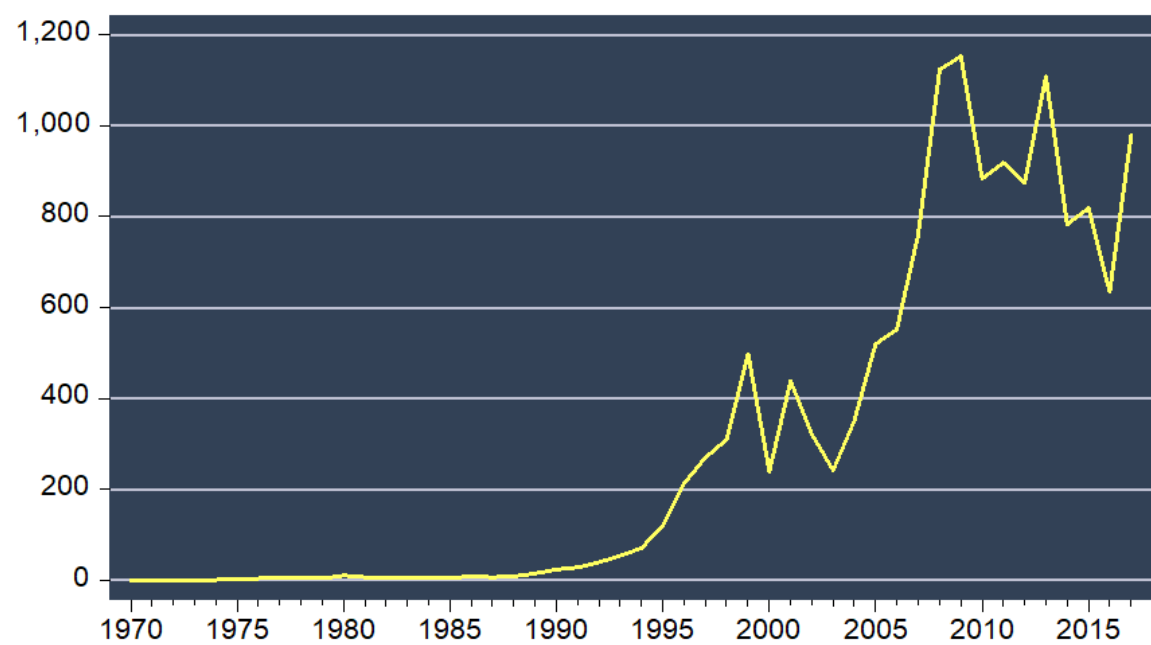

Figure 5. Graph Infrastructural Investment in Nigeria, 1970-2017

Source: E-views 9

Table 1. Analysis of Unit Root

\begin{tabular}{|c|c|c|c|c|}
\hline \multirow[t]{2}{*}{ Variables } & \multicolumn{2}{|c|}{ Calculated Values } & \multirow{2}{*}{$\begin{array}{c}\text { Critical Values } \\
5 \%\end{array}$} & \multirow{2}{*}{$\begin{array}{c}\text { Decisions } \\
\text { I(d) }\end{array}$} \\
\hline & Level & $1^{\text {st_ddiff. }}$ & & \\
\hline$I n M Q S_{t}$ & -1.6419 & -6.2036 & -3.5107 & $\mathrm{I}(1)$ \\
\hline $\ln P D I_{t}$ & -2.2896 & -4.9489 & -3.5107 & $\mathrm{I}(1)$ \\
\hline$I N F_{t}$ & -3.9399 & - & -3.5107 & $I(0)$ \\
\hline$I T R_{t}$ & -7.4391 & - & -3.5085 & $\mathrm{I}(0)$ \\
\hline $\ln E X R_{t}$ & -1.8846 & -5.5344 & -3.5107 & $\mathrm{I}(1)$ \\
\hline $\operatorname{lnINFS}_{t}$ & -1.8437 & -7.6233 & -3.5107 & $\mathrm{I}(1)$ \\
\hline
\end{tabular}

Source: E-views 9

\section{Data Analysis}

The analysis of the unit root was examined with univariate equation augmented by Dickey and Fuller. Inflation and interest rates behavior differently from the remaining four variables in the model; Inflation and interest are stationary while output of the manufacturing sub-sector, private domestic investment, infrastructural investment and effect of external prices estimated by the exchange rate of the naira to the US dollar are not stationary. Their integrating order from the examinations techniques revealed different order which are grouped as I(0) and I(1). Following the study of Pesaran, Smith and Shin (2001) on unit root and cointegration we are therefore, determine to apply the bound test to check the possibility of long-run relation among the variables in the model. The bound test analysis as shown on Table 2 indicates the possibility of the long run relationship among the variables in the model.

\section{Hypothesis Testing}

Null Hypothesis: No long-run relationships exist

Alternative Hypothesis: There is long run relationship

The hypothesis of cointegration is acknowledged because the F-Statistics is significant at the $5 \%$. 
Table 2. Cointegration Technique is the ARDL Bounds Test Method

\begin{tabular}{ccc}
\hline & Critical Value Bounds & I(1) Bound \\
\hline Significance & I(0) Bound & 3.52 \\
\hline $10 \%$ & 2.45 & 4.01 \\
\hline $5 \%$ & 2.86 & 4.49 \\
\hline $2.5 \%$ & 3.25 & 5.06 \\
\hline F-statistic & 3.74 & $\mathrm{~K}=4$ \\
\hline
\end{tabular}

Source: Researcher Computation with Statistical Software

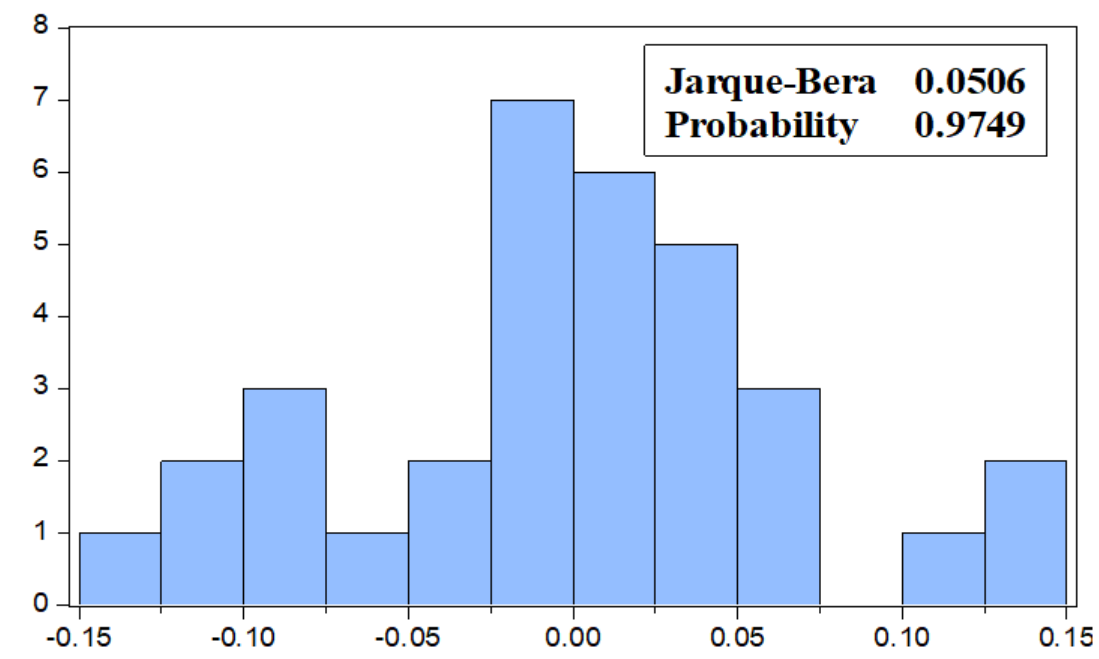

Figure 6. Normality Graph for the Model Residual Source: Eviews 9

Econometric research are mainly analyzed under two conditions, the statistical conditions which can be seen and classify as the first condition and the classical least square conditions which can be classify as the sufficient conditions. In the regard of this study we will emphasized the classical least square conditions and restrict ourselves to four of them which indicated that the residuals from the estimated equation shall be normality distributed with a zero mean and constancy of the variance of the residual as well as free of autocorrelation. Order conditions are stated and were properly defined in the model, etc.

The four assumptions are summarized in Figure 6 . The findings in all indicated that the model estimated satisfied the underlining four assumptions employed in the work.

Figure 6 shows that the Jarque-Bera which measures the statistical stability of the model is well behaved.

The model is estimated with the Autoregressive Distribution Lag (ARDL) estimator. The model estimated was selected with the Akaike Info. Criteria and was reported as $(1,0,0,0,0)$. The information on $\mathrm{R}^{2}$, Adjusted R-square, F-statistics, Durbin-Watson and Log Likelihood Ratios are then reported in Appendix.

\section{DISCUSSION OF FINDINGS}

The coefficients are reported based on economic theory and statistical criteria

\section{Manufacturing Sector Output and Private Domestic Investment in the Static Model}

Theoretically, positive relationships are expected between investment (either private, public, private, or foreign) and output, our model coefficient satisfies these conditions given the positive sign and value of the coefficient of PDI. The elasticity of both variables- output of the manufacturing sector and the private domestic investment in the static model is elastic. The outcomes of the output of the manufacturing sector to the changes in private domestic investment are above unitary, that is a one percent rise in PDI increases MSQ by $1.94 \%$ and the changes are vital to show by the statistical criteria. The implications are that investment from the private sector in the domestic economy will boost manufacturing more than the level of investment made by the investors' everything (domestic price, external price, infrastructural investment, and the prices of credits) being equal. The outcomes are in the same line with that of Kalu and Mgbemena (2015), Bakari (2017), and Oyedokun and Ajose (2018) that observed vital and positive links between private investment and economic output in Nigeria. We also notice that few of the works that are these studies are tested against did not follow the investment of infrastructures in their model.

The series employed as a check in the model behave differently the relation to economic theory and statistical conditions. Inflation rates were positive but statically insignificant; it was observed that responses of the output of the manufacturing sector to changes in the domestic price level (inflation) are perfectly inelastic. Thus, the output of the sector will be constant irrespective of the alterations in domestic prices of goods and services in Nigeria. 
Table 3. Ramsey Reset Test for Model Specification Bias

\begin{tabular}{cccc}
\hline & Specification: LOG(MSQ) LOG(MSQ(-1)) LOG(PDI) INF ITR LOG(INFS) C & Degree of Freedom & Probability \\
\hline & Value & 39 & 0.2040 \\
\hline t-statistic & 1.291757 & $(1,39)$ & 0.2040 \\
\hline F-statistic & 1.668636 & Degree of Freedom & Mean Square \\
\hline F-test summary: & Sum of Sq & 1 & 0.307704 \\
\hline Test SSR & 0.307704 & 40 & 0.187487 \\
\hline Restricted SSR & 7.499492 & 39 & 0.184405 \\
\hline
\end{tabular}

Source: Eviews 9

Table 4. Breusch-Godfrey Test of Serial Correlation

\begin{tabular}{cccc}
\hline & Value & Degree of Freedom & Probability \\
\hline F-statistic & 1.493070 & $F_{39}^{2}(2,38)$ & 0.2376 \\
\hline Obs $^{*} R^{2}$ & 3.424293 & $X_{0.05}^{2}(2)$ & 0.1805 \\
\hline Source: Eviews 9 & & &
\end{tabular}

Table 5. Heteroskedasticity Test of the Model Residual

\begin{tabular}{cccc}
\hline & Value & Degree of Freedom & Probability \\
\hline F-statistic & 2.277378 & $F_{41}^{5}(5,41)$ & 0.1552 \\
\hline Obs $^{\star} \mathrm{R}^{2}$ & 11.96738 & $X_{0.11}$ & $X_{0.05}^{2}(5)$ \\
\hline Scaled explained SS & 13.35802 & $X_{0.05}^{2}(5)$ & 0.2377 \\
\hline
\end{tabular}

Source: Eviews 9

Table 6. The Dynamic Model

\begin{tabular}{|c|c|c|c|c|}
\hline \multicolumn{5}{|c|}{ Cointegrating Form Model Coefficients } \\
\hline Variables & Coeff. & Std. Error & t-test val. & Prob. \\
\hline$D \ln P D I_{t}$ & 0.482340 & 0.147014 & 3.280918 & 0.0022 \\
\hline$D I N F_{t}$ & 0.007460 & 0.004777 & 1.561554 & 0.1263 \\
\hline$D I T R_{t}$ & -0.021369 & 0.004918 & -4.34105 & 0.0001 \\
\hline$D \ln E X R_{t}$ & -0.257908 & 0.109476 & -2.355837 & 0.0235 \\
\hline$D \operatorname{lnINFS} S_{t}$ & 0.166583 & 0.114996 & 1.448598 & 0.1552 \\
\hline$E C M_{t-1}$ & -0.249091 & 0.077304 & -3.222246 & 0.0025 \\
\hline \multicolumn{5}{|c|}{$\begin{aligned} \text { Cointeq }= & \text { LOG(MSQ) }-\left(1.9364^{\star} \text { LOG(PDI) }-0.0300^{\star} \text { INF }-0.0858^{\star} \text { ITR }\right. \\
& \left.-1.0354^{\star} \text { LOG }(\text { EXR })+0.6688^{\star} \text { LOG }(\text { INFS })-0.2947\right)\end{aligned}$} \\
\hline
\end{tabular}

Source: Eviews 9

Table 7. The Static Model

\begin{tabular}{|c|c|c|c|c|}
\hline \multicolumn{5}{|c|}{ Long Run Coefficients } \\
\hline Variable & Coefficient & Std. Error & t-Statistic & Prob. \\
\hline$C_{t}$ & -0.294696 & 0.729871 & -0.403764 & 0.6885 \\
\hline $\ln P D I_{t}$ & 1.936400 & 0.372461 & 5.198931 & 0.0000 \\
\hline$I N F_{t}$ & 0.029950 & 0.023709 & 1.263230 & 0.2138 \\
\hline$I T R_{t}$ & -0.085789 & 0.035408 & -2.422858 & 0.0200 \\
\hline $\ln E X R_{t}$ & -1.035398 & 0.406976 & -2.544127 & 0.0149 \\
\hline $\operatorname{lnINFS_{t}}$ & 0.668765 & 0.401575 & 2.624892 & 0.0120 \\
\hline
\end{tabular}

Source: Eviews 9

Exchange rate (external prices) and cost of investment or capital or credit (interest) are significant and negative in the long run. Exchange rates have a unitary elastic link with the output of the manufacturing sector in the model showing that a one percent appreciation or depreciation of the naira to the US dollar will lead to a $1 \%$ decrease/increase in the manufacturing sector output in Nigeria in the long run. The exact relationship of the cost of credits is perfectly inelastic, thus the output will rise or reduce irrespective of the raise or reduction in the level of prices of credits.

\section{Manufacturing Sector Output and Private Domestic Investment in the Dynamic Model}

Theoretically, a positive relationship is expected between investment (either private, public, private or foreign) and output more specifically in the short run, our model coefficient satisfies these conditions given the positive value of the coefficient of PDI in the dynamic model. The elasticity of both variables- output of the manufacturing sector and private domestic investment in the dynamic model is inelastic. The responses of the output of the manufacturing sector to the changes in private domestic investment are below unitary, which is a 100\% increase in PDI increases MSQ by $48 \%$ and the changes are significant as shown by the statistical criteria. The implication is that investment from private investors in the domestic economy will boost manufacturing less than the level of investment made by the investors' everything (domestic price, external price, infrastructural investment, and price of credits) being equal. 
The findings are in line with the work of Kalu and Mgbemena (2015), and Oyedokun and Ajose (2018) that observed a significant and positive relationship between private investment and economic output in Nigeria. We also notice that many of the works that are these studies are tested against did not account for the investment of infrastructures in their model, which have a significant positive impact on output in the model in the long-run.

The variables used as check-in the model behave differently in terms of economic theory and statistical conditions. Inflation rates were positive but statically insignificant, it was equally observed that responses of the output of the manufacturing sector to changes in the domestic price level (inflation) are perfectly inelastic as shown in the long-run model. Thus, the output of the sector will remain the same irrespective of the changes in domestic prices of goods and services in Nigeria. This implies that the period is of no effect in the angel of the domestic prices and the output of the manufacturing sector in our model.

The exchange rate (external prices) and cost of investment or capital or credit (interest) are significant and negative in the long-run. The exchange rate has an inelastic link with the output of the manufacturing sector in the model indicating that $1 \%$ appreciation/depreciation of the naira to the US dollar will result to less than one percent decrease/increase in the output of the manufacturing sector in the analysis of the short-run in Nigeria. The relationship between the cost of credits is also fairly inelastic. The volume of the investment on the infrastructures is positive and direct in both equations of the study but has a heavy effect in the long run than that of the short-run period.

\section{Comparative Analysis of Static and Dynamic Models}

Investment is statistically significant in both the static and dynamic models. Also, in both models investment indicator shows a positive relationship with MSQ. The result implies that both past and present investment decisions are imperative to boost MSQ in Nigeria.

\section{Summary of Major Findings}

The major findings in this study are summarized and listed as follows through the three approaches used in the course of our analysis:

1. There was over $82 \%$ increase in the output of the manufacturing sector in the late 1970 s and early 1980 s and over $98 \%$ increase the output of the manufacturing sector in the late within 2010 and 2015;

2. It was uncovered that a rise in the activities of the manufacturing sector in the late 1970s and early 1980 s are associated to the Asian Gulf war and international trade policy during that period; also the tremendous increase in 2010 was traceable to the point of change in the statistical formulation of economic growth in the economy;

3. Four variables in the models are not stationary, they are the output of the manufacturing sector, private domestic investment, the foreign exchange rates and investment levels on the infrastructures but they were integrated at the order of $I(1)$;

4. Two series in the stated equation are stationary, they are inflation rates and interest rate;

5. It means that the series in the formulated model are integrated differently and are cointegrated at $5 \%$.

6. The estimated models have residuals that are normally distributed with a zero mean, free from the presence of serial correlation and heteroscedasticity;

7. It was equally shown that the equation was properly and correctly specify;

8. The responses of the output of the manufacturing sector to Private domestic investment are positive and highly significant in both models. It was fairly elastic in the static model and fairly inelastic in the dynamic;

9. The outcome of the output of the manufacturing sector to the rate of inflation is positive but insignificant in both models. It shows a perfectly inelastic response in both models;

10. The response of the output of the manufacturing sector to the rate of interest was significant but negative in both models. It shows a perfectly inelastic response in the dynamic model and fairly inelastic in the static model;

11. The response of the output of the manufacturing sector to changes in the foreign rate of exchanges of the naira/US dollar was negative and significant in both models. It was fairly elastic in the static model and fairly inelastic in the dynamic;

12. The responses of the output of the manufacturing sector to alteration to the level of investment in infrastructure are positive and significant in the static model and insignificant in the dynamic model. It shows a fairly inelastic response in the dynamic and static models;

13. Finally, it was shown that the model has a weak adjustment mechanism. The adjustment of disequilibrium between static and dynamic equilibrium is weak or just $24.9 \%$.

\section{CONCLUSION}

From the findings of the result, we could conclude that investment is an effective policy instrument to accelerate the manufacturing sector. Thus, there is a positive impact on investment in the manufacturing sector. Any conscious policy direction to improve investment inflow into the manufacturing sector would cause a multiplier effect stimulating aggregate output which in turn would affect the employment of labour resources. The implication of the significant and positive of investment implies that for the country to industrialize and gain market share in the global market there has to be a corresponding inflow of investible 
funds into the sector and the sector should be able to attract investment. This would in turn improve the capacity of the sector to contribute to growth (GDP).

There are different kinds of investments that enable an economy to objective the goal or point of the desired aggregate level of output and jobs opportunities to existing, foreign private, foreign public (official development assistance), public domestic and private domestic investment. In this analysis, we examine only how private domestic investments have enhanced the level of economic growth and the performances of the Nigerian manufacturing sector from 1970 to 2017 . The study demonstrated this with six macroeconomic variables one from each sector of the economy. The statistical outcomes of the used variables were different which makes us adopt the ARDL to estimate the model because the technique is robust in handling variables with a different order of integration that is not greater than I(1). The computed summary of the result demonstrated that private domestic investment has contributed greatly to the growth and performances of the manufacturing sector. Hence the summary and conclusion are that the role of the private domestic investment to the enhancement of the manufacturing performance is not linear and that investments are needed in the area of infrastructures especially in the short-term for this sector to blossom.

\section{RECOMMENDATIONS}

From the summary and conclusions, we fashioned the following recommendations listed below

\section{Policy Recommendation}

1. Since private domestic investment is vital, positive, and significant in enhancing the activities of the manufacturing sector irrespective of the period or zone, the study recommended an increasing level of credit to the private sector the apex monetary authority.

2. We noticed from the analysis that the level of investment in infrastructures is vital and paramount in causing economic growth and also the performance of the manufacturing sector in long-term but its effect was very weak in the short-term given that investment in infrastructures is relegated to be public investment, hence we recommend the public and private sectors partnership in raising the level and standard of infrastructures to enhance its effect to the manufacturing sector.

3. The model shows those rates of interest are vital and important in causing the long-run and short-run period to the manufacturing sector and it was also properly and correctly sign, hence we recommended special interest for the manufacturing sector and should be monitored by the apex bank.

4. The study also recommends that the special exchange rate channel to investment should be monitored by the economicfinancial crime commission, $\mathrm{CBN}$, and the independent corrupt practice commission.

\section{REFERENCES}

Ade-Agoye, I. (2011). Man Ikeja holds AGM and expresses worry over poor contribution of manufacturing sector to GDP. Manufacturing Association of Nigeria News. p8.

Aftalian, A. (1911). “Les Trois Notions de la Productivit • et les Revenues”, 1911, Revue d'Economie Politique.

Agu, O. C. (2015). Determinants of private investment in Nigeria: An econometric analysis. International Journal of Economics, Commerce and Management, III(4), 2-14.

Ahiawodzi, A. K. and Adade. T. C. (2012). Access to credit and growth of small and medium scale enterprsie in the Ho municpality of Ghana. British Journal of Economics, Finance and Management Sciences, 6(2), 34-51.

Ajose, K. and Oyedokun, G. E. (2018). Capital formation and economic growth in Nigeria. International Journal of Finance and Banking Studies, 7, 2147-4486. https://doi.org/10.20525/ijfbs.v7i3.37

Ajudua, E. I. and Ojima, D. (2016). Modelling the determinants of output in the Nigerian manufacturing sector. International Journal of Innovative Finance and Economics Reseaerch, 4(1), 1-12.

Akpansung, A. O. and Babalola, S. J. (2011). Banking sector cresit and economic grwoth in Nigeria: AN emprical investigation. CBN Journal of Applied Statistics, 2(2), 51-62.

Anetor, F., Ogebchie, C., Kelikume, I. and Ikesu, F. (2016). Credit supply and agriacultyural production in Nigeria: A vector autoregressive (VAR) approach. Journal of Economics and Sustainable Development, 7(2), 131-140.

Anthony, O. (2012). Banking savings and bank credits in Nigeria: Determinants and impact on economic growth: International Journal of Economics and Financial Issues, 2(3), 357-372.

Anyanwu, J. C. (1997). The structure of the Nigerian economy (1960-1997). Joanee educational Publishers.

Ashraf, A. and Herzer, D. (2014). The effects of Greenfield investment, competition and industrial development in developing countries. Applied Economics Letters, 21(14), 997-1000. https://doi.org/10.1080/13504851.2014.904482

Bader, M. and Ibrahim, M. A. (2010). The impact of interest rate on investment in Jordan: a cointegration Analysis. Journal of King Abdul Aziz University, Economics and Administration, 24(1), 199-209. https://doi.org/10.4197/Eco.24-1.6

Bakari, S. (2017). The impact of domestic investment on economic growth: New evidence from Malaysia. MPRA_paper_79436.pdf 
Bakari, S. (2017). The Nexus between Export, Import, Domestic Investment and Economic Growth in Japan. MPRA Paper. 76110 , University Library of Munich, Germany.

Chen, G. S., Yao, Y. and Malizard, J. (2017). Does foreign direct investment crowd in or crowd out private domestic investment in China? The effect of entry mode. Economic Modelling, 61, 409-419. https://doi.org/10.1016/j.econmod.2016.11.005

Chinweoke, N., Egwu, C. C. and Nwabeka, C. E. (2015). Impact of commercials banks' loans and advances to agriculture and manufactruing sector on economic grwoth of Nigeria (1994-2013). International Journal of Arts and Science, 08(05), 29-36.

Clark, J. M. (1917). Business Acceleration and the Law of Demand. 1917, JPE.

Cristina. J. (2018). Does FDI crowd out domestic investment in transition countries?. Economics of Transition, 27(1), 163-200. https://doi.org/10.1111/ecot.12184

Ekanem, I. U. (2002). The investment decision-making process in small manufacturing enterprise: With particular reference to printing and clothing industries (PhD thesis), Middlesex University Research Repository.

Engel, R. F. and Granger, C. W. J. (1987). Co-integration and Error correction: Representation, Estimation, and Testing. Econometrica: Journal of the Econometric Society, 55, 251-276. https://doi.org/10.2307/1913236

Ghazali, A. (2010). Analyzing the relationship between foreign direct investment domestic investment and economic growth for Pakistan. International Research Journal of Finance and Economics, 47(47), 124-131.

Granger, C. W. J (1981). Some properties of the time series data and their use in econometric model specification. Journal of Econometrics, 16, 121-130. https://doi.org/10.1016/0304-4076(81)90079-8

Jhingan, M. L. (2008). The Economics of Development and Planning (39 th ed.), Delhi, Vrinda Publications (P) Ltd, p. 439.

John E. E. and Terhemba, I. P. (2016). Commerial bank credit and manufacturing sector output in Nigeria. Journal of Economics and Sustainable Development, 7(16).

Kalu, C. U. and Mgbemena, O. O. (2015). Domestic private investment and economic growth in Nigeria: Issues and further consideration. International Journal Academic Research in Business and Social Sciences, 5(10), 79-88. https://doi.org/10.6007/IJARBSS/v5-i2/1489

Kehinde, A. O., Felix, A., Kayode, K. and Adedamola, F. A. (2012). The determinants of domestic private investment in Nigeria. IOSR Journal of Humanities and Social Sciences, 2(6), 46-54. https://doi.org/10.9790/0837-0264654

Korkmaz, S. (2015). Impact of bank credits on Economic grwith and Inflation. Journal of Applied Finance and Banking, 5(1), 57-69.

Mamman, A. and Hashim, Y. A. (2013). Impact of Private Sector Credit on the Real Sector of Nigeria. International Journal of Business and Social Research, 3(5), 105-116.

Nwakanma, P. C., Nnamdi, I. S. and Omojefe, G. O. (2014). Bank credits to the private sector: potency and relevance in Nigeria's economic growth process. Sciedu Press Research Accounting and Finance, 3(2), 23-35. https://doi.org/10.5430/afr.v3n2p23

Obamuyi, M. T., Edun, A. T. and Kayode, O. F. (2012). Bank lending, economic grwoth and the performance of the manufacturing sector in Nigeria. European Scientific Journal, 8(3).

Obilor, S. I. (2013). The impact of commercial Banks' credit to agricultural on agricultural development in Nigeria: An econometric analysis. International Journal of Business, Humanities, and Technology, 3(1), 85-94.

Odufuye, B. M. (2017). Bank credits and its impact on Nigerian economy growth. International Journal of Development Strategies in Humanities, Management and Social Sciences, 7(3), 39-52.

Ogar, A., Nkamare, S. E. and Effiong, C. (2014). Commercial banks credit and its contribution on maufacturing sector in Nigeria. Research Journal of Finance and Accounting, 5(22).

Okoye, N. (2017). Investment in entrepreneurship: Investment mobilization as a solution to capital raising and industrial capacity. Available at: https://www.nickyokoye.com/articles/78/investment-in-entrepreneurship-investment-mobilization-as-asolution-to-capital-raising-and-industrial-capacity

Oluitan, R. (2012). Financial development and economic grwoth in Africa: lessons and prospects. Business and Economic Research, Macrothink Insitute, 2(2), 54-67. https://doi.org/10.5296/ber.v2i2.2205

Omankhanlen, O. and Owonibi, A. (2012). Manufacturers and burden of high interest rates. July, 29, 2012.

Oni, I. O., Akinlo, A. E. and Oladepo, E. D. (2014). Impact of bank credit on the real sector: Evidence from Nigeria. Global Journal of Business Research, 8(3), 39-47.

Pesaran, M. H., Shin, Y. and Smith, R. J. (2001). Bounds testing approaches to the analysis of level relationships. Journal of Applied Econometrics, 16(3), 289-329. https://doi.org/10.1002/jae.616

Qin, D., Cagas, M. A., Quising, P. and He, X.-H. (2006). How much does investment drive economic growth in China? Journal of Policy Modeling, 28(7), 751-774. https://doi.org/10.1016/j.jpolmod.2006.02.004

Sogules, I. W. and Nkoro, E. (2016). Bank credits and performance of agricultural and manufacuring sector, 1970-2013. Business, Management and Economics Research, Academic Research Publising Group, 2(5), 90-95.

Ume, K. E., Obasikene, A. C., Oleka, D. C., Nwadike, A. O. and Okoyeuzu, C. (2017). The relative impact of bank credit on manufacturing sector in Nigeria. International Journal of Economics and Financial Issues, 7(2), 196-201. 


\section{APPENDIX}

\section{Data Presentation}

Table 1. Data on Manufacturing Sector Output, Private Domestic Investment, Real Lending Rates, Inflation Rates Exchange Rates and Infrastructures Investment

\begin{tabular}{|c|c|c|c|c|c|c|}
\hline YEAR & MSQ (N'Billion) & PDI (N'Billion) & RLR & INF & EXR & INFS (N'Billion) \\
\hline 1970 & 0.32 & 0.36 & -29.27 & 13.76 & 0.71 & 0.19 \\
\hline 1971 & 0.31 & 0.54 & 5.58 & 16.00 & 0.71 & 0.17 \\
\hline 1972 & 0.38 & 0.65 & 3.99 & 3.46 & 0.66 & 0.45 \\
\hline 1973 & 0.47 & 0.75 & 1.57 & 5.40 & 0.66 & 0.57 \\
\hline 1974 & 1.18 & 0.90 & -25.67 & 12.67 & 0.63 & 1.22 \\
\hline 1975 & 1.19 & 1.34 & -13.97 & 33.96 & 0.62 & 3.21 \\
\hline 1976 & 1.46 & 2.06 & -6.87 & 24.30 & 0.63 & 4.04 \\
\hline 1977 & 1.70 & 2.87 & -4.26 & 15.09 & 0.64 & 5.00 \\
\hline 1978 & 2.17 & 4.06 & -6.29 & 21.71 & 0.64 & 5.20 \\
\hline 1979 & 2.60 & 4.90 & -11.29 & 11.71 & 0.60 & 4.22 \\
\hline 1980 & 3.49 & 6.23 & -3.55 & 9.97 & 0.55 & 10.16 \\
\hline 1981 & 13.84 & 8.57 & -8.06 & 20.81 & 0.62 & 6.57 \\
\hline 1982 & 15.63 & 10.67 & 4.49 & 7.70 & 0.67 & 6.42 \\
\hline 1983 & 10.80 & 11.67 & -3.33 & 23.21 & 0.72 & 4.89 \\
\hline 1984 & 9.53 & 12.46 & -2.67 & 17.82 & 0.77 & 4.10 \\
\hline 1985 & 12.03 & 13.07 & 3.69 & 7.44 & 0.89 & 5.46 \\
\hline 1986 & 11.58 & 15.25 & -1.50 & 5.72 & 1.75 & 8.53 \\
\hline 1987 & 12.04 & 21.08 & -31.92 & 11.29 & 4.02 & 6.37 \\
\hline 1988 & 13.71 & 27.33 & -5.13 & 54.51 & 4.54 & 8.34 \\
\hline 1989 & 14.01 & 30.40 & -16.96 & 50.47 & 7.36 & 15.03 \\
\hline 1990 & 14.70 & 33.55 & 14.65 & 7.36 & 8.04 & 24.05 \\
\hline 1991 & 16.08 & 41.35 & 2.07 & 13.01 & 9.91 & 28.34 \\
\hline 1992 & 15.36 & 58.12 & -25.77 & 44.59 & 17.30 & 39.76 \\
\hline 1993 & 14.79 & 127.12 & 4.37 & 57.17 & 22.07 & 54.50 \\
\hline 1994 & 14.59 & 143.42 & -8.03 & 57.03 & 22.00 & 70.92 \\
\hline 1995 & 13.84 & 180.00 & -43.57 & 72.84 & 21.90 & 121.14 \\
\hline 1996 & 13.95 & 238.60 & -9.71 & 29.27 & 21.88 & 212.93 \\
\hline 1997 & 14.01 & 316.21 & 16.61 & 8.53 & 21.89 & 269.65 \\
\hline 1998 & 13.05 & 351.96 & 25.28 & 10.00 & 21.89 & 309.02 \\
\hline 1999 & 13.49 & 431.17 & 2.77 & 6.62 & 92.34 & 498.03 \\
\hline 2000 & 13.96 & 530.37 & -10.32 & 6.93 & 101.70 & 239.45 \\
\hline 2001 & 14.94 & 764.96 & 23.84 & 18.87 & 111.23 & 438.70 \\
\hline 2002 & 16.44 & 930.49 & -10.81 & 12.88 & 120.58 & 321.38 \\
\hline 2003 & 17.37 & 1096.54 & 8.61 & 14.03 & 129.22 & 241.69 \\
\hline 2004 & 19.44 & 1421.66 & 19.37 & 15.00 & 140.85 & 351.30 \\
\hline 2005 & 21.31 & 1838.39 & -3.34 & 17.86 & 142.56 & 519.50 \\
\hline 2006 & 23.31 & 2290.62 & -0.37 & 8.24 & 137.10 & 552.39 \\
\hline 2007 & 25.54 & 3680.09 & 11.61 & 5.38 & 127.41 & 759.32 \\
\hline 2008 & 27.81 & 6941.38 & 4.19 & 11.58 & 120.71 & 1123.46 \\
\hline 2009 & 29.99 & 9147.42 & 23.71 & 11.54 & 161.64 & 1152.80 \\
\hline 2010 & 1018.91 & 9830.34 & -42.31 & 13.72 & 153.06 & 883.87 \\
\hline 2011 & 1416.79 & 14183.59 & 5.94 & 10.84 & 159.31 & 918.55 \\
\hline 2012 & 1373.66 & 15151.76 & 6.88 & 12.22 & 160.86 & 874.83 \\
\hline 2013 & 1398.10 & 16191.47 & 10.25 & 8.48 & 162.45 & 1108.39 \\
\hline 2014 & 1618.25 & 18126.05 & 11.36 & 8.06 & 171.45 & 783.12 \\
\hline 2015 & 1665.09 & 18720.51 & 13.60 & 9.02 & 222.72 & 818.37 \\
\hline 2016 & 1670.73 & 21982.15 & 6.69 & 15.70 & 372.86 & 634.80 \\
\hline 2017 & 1829.34 & 22290.66 & 11.14 & 18.88 & 395.70 & 979.50 \\
\hline
\end{tabular}

Source: CBN Bulletin and Statistical Reports, 2010 and 2017 Editions 


\section{Results}

Null Hypothesis: LOG(MSQ) has a unit root

Exogenous: Constant, Linear Trend

Lag Length: 0 (Automatic - based on SIC, maxlag=9)

\begin{tabular}{llll}
\hline \hline & & t-Statistic & Prob. $^{*}$ \\
\hline \hline Augmented Dickey-Fuller test statistic & & -1.641882 & 0.7608 \\
\hline Test critical values: & $1 \%$ level & -4.165756 & \\
& $5 \%$ level & -3.508508 & \\
& $10 \%$ level & -3.184230 & \\
\hline \hline
\end{tabular}

*MacKinnon (1996) one-sided p-values.

Augmented Dickey-Fuller Test Equation

Dependent Variable: D(LOG(MSQ))

Method: Least Squares

Date: 03/18/19 Time: 08:43

Sample (adjusted): 19712017

Included observations: 47 after adjustments

\begin{tabular}{|c|c|c|c|c|}
\hline Variable & Coefficient & Std. Error & t-Statistic & Prob. \\
\hline LOG(MSQ(-1)) & -0.125340 & 0.076339 & -1.641882 & 0.1077 \\
\hline $\mathrm{C}$ & 0.054294 & 0.173019 & 0.313802 & 0.7552 \\
\hline @TREND(“1970”) & 0.019913 & 0.012584 & 1.582464 & 0.1207 \\
\hline R-squared & 0.059406 & \multicolumn{2}{|c|}{ Mean dependent var } & 0.184067 \\
\hline Adjusted R-squared & 0.016652 & \multicolumn{2}{|c|}{ S.D. dependent var } & 0.559272 \\
\hline S.E. of regression & 0.554596 & \multicolumn{2}{|c|}{ Akaike info criterion } & 1.720549 \\
\hline Sum squared resid & 13.53339 & \multicolumn{2}{|c|}{ Schwarz criterion } & 1.838644 \\
\hline Log likelihood & -37.43290 & \multicolumn{2}{|c|}{ Hannan-Quinn criter. } & 1.764989 \\
\hline F-statistic & 1.389474 & \multirow{2}{*}{\multicolumn{2}{|c|}{ Durbin-Watson stat }} & 1.766253 \\
\hline Prob(F-statistic) & 0.259926 & & & \\
\hline
\end{tabular}

Null Hypothesis: D(LOG(MSQ)) has a unit root

Exogenous: Constant, Linear Trend

Lag Length: 0 (Automatic - based on SIC, maxlag=9)

\begin{tabular}{llll}
\hline \hline & & t-Statistic & Prob. $^{*}$ \\
\hline \hline Augmented Dickey-Fuller test statistic & & -6.203567 & 0.0000 \\
\hline Test critical values: & $1 \%$ level & -4.170583 & \\
& $5 \%$ level & -3.510740 & \\
& $10 \%$ level & -3.185512 & \\
\hline \hline
\end{tabular}

*MacKinnon (1996) one-sided p-values.

Augmented Dickey-Fuller Test Equation

Dependent Variable: D(LOG(MSQ),2)

Method: Least Squares

Date: 03/18/19 Time: 08:43

Sample (adjusted): 19722017

Included observations: 46 after adjustments

\begin{tabular}{lcccc}
\hline \hline Variable & Coefficient & Std. Error & t-Statistic & Prob. \\
\hline \hline D(LOG(MSQ(-1))) & -0.944072 & 0.152182 & -6.203567 & 0.0000
\end{tabular}




\begin{tabular}{|c|c|c|c|c|}
\hline $\begin{array}{l}\text { C } \\
\text { @TREND(“1970”) }\end{array}$ & $\begin{array}{l}0.151614 \\
0.001091\end{array}$ & $\begin{array}{l}0.179538 \\
0.006409\end{array}$ & $\begin{array}{l}0.844467 \\
0.170274\end{array}$ & $\begin{array}{l}0.4031 \\
0.8656\end{array}$ \\
\hline R-squared & 0.472418 & Mean dependent var & & 0.002662 \\
\hline Adjusted R-squared & 0.447879 & S.D. dependent var & & 0.775659 \\
\hline S.E. of regression & 0.576352 & Akaike info criterion & & 1.798798 \\
\hline Sum squared resid & 14.28383 & Schwarz criterion & & 1.918058 \\
\hline Log likelihood & -38.37236 & Hannan-Quinn criter. & & 1.843474 \\
\hline F-statistic & 19.25192 & Durbin-Watson stat & & 1.988169 \\
\hline Prob(F-statistic) & 0.000001 & & & \\
\hline
\end{tabular}

Null Hypothesis: LOG(PDI) has a unit root

Exogenous: Constant, Linear Trend

Lag Length: 1 (Automatic - based on SIC, maxlag=9)

\begin{tabular}{llll}
\hline \hline & & t-Statistic & Prob.* $^{*}$ \\
\hline \hline Augmented Dickey-Fuller test statistic & & -2.289593 & 0.4309 \\
\hline Test critical values: & $1 \%$ level & -4.170583 & \\
& $5 \%$ level & -3.510740 & \\
& $10 \%$ level & -3.185512 & \\
\hline \hline
\end{tabular}

*MacKinnon (1996) one-sided p-values.

Augmented Dickey-Fuller Test Equation

Dependent Variable: D(LOG(PDI))

Method: Least Squares

Date: 03/18/19 Time: 08:44

Sample (adjusted): 19722017

Included observations: 46 after adjustments

\begin{tabular}{|c|c|c|c|c|}
\hline Variable & Coefficient & Std. Error & t-Statistic & Prob. \\
\hline LOG(PDI(-1)) & -0.205045 & 0.089555 & -2.289593 & 0.0271 \\
\hline $\mathrm{D}(\operatorname{LOG}(\operatorname{PDI}(-1)))$ & 0.379764 & 0.149959 & 2.532452 & 0.0152 \\
\hline $\mathrm{C}$ & -0.070264 & 0.129588 & -0.542211 & 0.5905 \\
\hline @TREND(“1970”) & 0.049089 & 0.021983 & 2.233081 & 0.0309 \\
\hline R-squared & 0.186520 & \multicolumn{2}{|c|}{ Mean dependent var } & 0.231046 \\
\hline Adjusted R-squared & 0.128414 & \multicolumn{2}{|c|}{ S.D. dependent var } & 0.152479 \\
\hline S.E. of regression & 0.142352 & \multicolumn{2}{|c|}{ Akaike info criterion } & -0.978085 \\
\hline Sum squared resid & 0.851093 & \multicolumn{2}{|c|}{ Schwarz criterion } & -0.819073 \\
\hline Log likelihood & 26.49596 & \multicolumn{2}{|c|}{ Hannan-Quinn criter. } & -0.918518 \\
\hline F-statistic & 3.210006 & \multicolumn{2}{|c|}{ Durbin-Watson stat } & 1.918667 \\
\hline Prob(F-statistic) & 0.032501 & & & \\
\hline
\end{tabular}

Null Hypothesis: D(LOG(PDI)) has a unit root Exogenous: Constant, Linear Trend

Lag Length: 0 (Automatic - based on SIC, maxlag=9)

\begin{tabular}{llll}
\hline \hline & & t-Statistic & Prob.* $^{*}$ \\
\hline \hline Augmented Dickey-Fuller test statistic & & -4.948914 & 0.0011 \\
\hline Test critical values: & $1 \%$ level & -4.170583 & \\
& $5 \%$ level & -3.510740 & \\
& $10 \%$ level & -3.185512 & \\
\hline \hline
\end{tabular}


*MacKinnon (1996) one-sided p-values.

Augmented Dickey-Fuller Test Equation

Dependent Variable: D(LOG(PDI),2)

Method: Least Squares

Date: 03/18/19 Time: 08:45

Sample (adjusted): 19722017

Included observations: 46 after adjustments

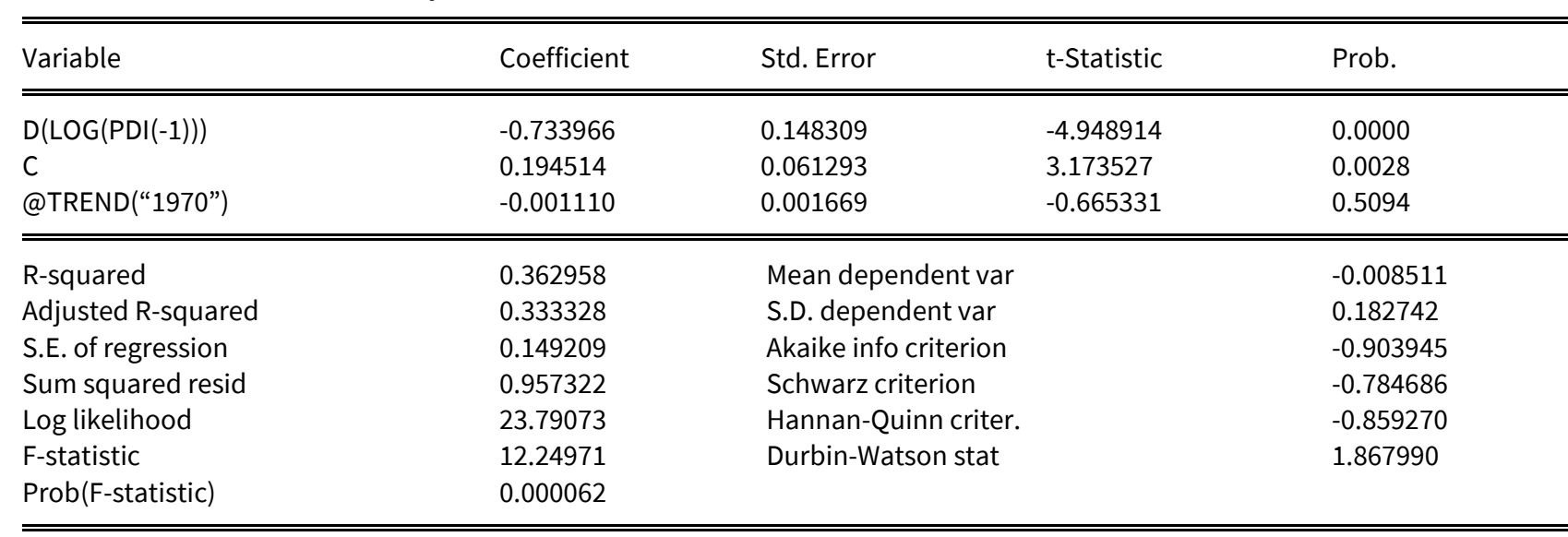

Null Hypothesis: INF has a unit root

Exogenous: Constant, Linear Trend

Lag Length: 1 (Automatic - based on SIC, maxlag=9)

\begin{tabular}{llll}
\hline \hline & & t-Statistic & Prob.* $^{*}$ \\
\hline \hline Augmented Dickey-Fuller test statistic & & -3.939923 & 0.0181 \\
\hline Test critical values: & $1 \%$ level & -4.170583 & \\
& $5 \%$ level & -3.510740 & \\
& $10 \%$ level & -3.185512 & \\
\hline \hline
\end{tabular}

Augmented Dickey-Fuller Test Equation

Dependent Variable: D(INF)

Method: Least Squares

Date: 03/18/19 Time: 08:46

Sample (adjusted): 19722017

Included observations: 46 after adjustments

\begin{tabular}{|c|c|c|c|c|}
\hline Variable & Coefficient & Std. Error & t-Statistic & Prob. \\
\hline $\operatorname{INF}(-1)$ & -0.528536 & 0.134149 & -3.939923 & 0.0003 \\
\hline $\mathrm{D}(\mathrm{INF}(-1))$ & 0.280794 & 0.147758 & 1.900360 & 0.0643 \\
\hline $\mathrm{C}$ & 11.87480 & 4.976421 & 2.386212 & 0.0216 \\
\hline @TREND(“1970”) & -0.079290 & 0.144855 & -0.547374 & 0.5870 \\
\hline R-squared & 0.270135 & \multicolumn{2}{|c|}{ Mean dependent var } & 0.062609 \\
\hline Adjusted R-squared & 0.218001 & \multicolumn{2}{|c|}{ S.D. dependent var } & 14.62712 \\
\hline S.E. of regression & 12.93487 & \multicolumn{2}{|c|}{ Akaike info criterion } & 8.040671 \\
\hline Sum squared resid & 7027.051 & \multicolumn{2}{|c|}{ Schwarz criterion } & 8.199683 \\
\hline Log likelihood & -180.9354 & \multicolumn{2}{|c|}{ Hannan-Quinn criter. } & 8.100238 \\
\hline F-statistic & 5.181618 & \multicolumn{2}{|c|}{ Durbin-Watson stat } & 1.870606 \\
\hline Prob(F-statistic) & 0.003888 & & & \\
\hline
\end{tabular}


Null Hypothesis: ITR has a unit root Exogenous: Constant, Linear Trend Lag Length: 0 (Automatic - based on SIC, maxlag=9)

\begin{tabular}{llll}
\hline \hline & & t-Statistic & Prob.* $^{*}$ \\
\hline \hline Augmented Dickey-Fuller test statistic & & -7.439083 & 0.0000 \\
\hline Test critical values: & $1 \%$ level & -4.165756 & \\
& $5 \%$ level & -3.508508 & \\
& $10 \%$ level & -3.184230 & \\
\hline \hline
\end{tabular}

*MacKinnon (1996) one-sided p-values.

Augmented Dickey-Fuller Test Equation

Dependent Variable: D(ITR)

Method: Least Squares

Date: 03/18/19 Time: 08:47

Sample (adjusted): 19712017

Included observations: 47 after adjustments

\begin{tabular}{|c|c|c|c|c|}
\hline Variable & Coefficient & Std. Error & t-Statistic & Prob. \\
\hline $\operatorname{ITR}(-1)$ & -1.096888 & 0.147449 & -7.439083 & 0.0000 \\
\hline $\mathrm{C}$ & -10.66181 & 4.709178 & -2.264049 & 0.0286 \\
\hline @TREND(“1970”) & 0.388805 & 0.169702 & 2.291103 & 0.0268 \\
\hline R-squared & 0.557367 & \multicolumn{2}{|c|}{ Mean dependent var } & 0.859787 \\
\hline Adjusted R-squared & 0.537247 & \multicolumn{2}{|c|}{ S.D. dependent var } & 21.81482 \\
\hline S.E. of regression & 14.83973 & \multicolumn{2}{|c|}{ Akaike info criterion } & 8.294195 \\
\hline Sum squared resid & 9689.575 & \multicolumn{2}{|c|}{ Schwarz criterion } & 8.412289 \\
\hline Log likelihood & -191.9136 & \multicolumn{2}{|c|}{ Hannan-Quinn criter. } & 8.338635 \\
\hline F-statistic & 27.70259 & \multirow{2}{*}{\multicolumn{2}{|c|}{ Durbin-Watson stat }} & 1.965029 \\
\hline Prob(F-statistic) & 0.000000 & & & \\
\hline
\end{tabular}

Null Hypothesis: LOG(EXR) has a unit root

Exogenous: Constant, Linear Trend

Lag Length: 0 (Automatic - based on SIC, maxlag=9)

\begin{tabular}{llll}
\hline \hline & & t-Statistic & Prob. $^{*}$ \\
\hline \hline Augmented Dickey-Fuller test statistic & & -1.884574 & 0.6467 \\
\hline Test critical values: & $1 \%$ level & -4.165756 & \\
& $5 \%$ level & -3.508508 & \\
& $10 \%$ level & -3.184230 & \\
\hline \hline
\end{tabular}

*MacKinnon (1996) one-sided p-values.

Augmented Dickey-Fuller Test Equation

Dependent Variable: D(LOG(EXR))

Method: Least Squares

Date: 03/18/19 Time: 08:48

Sample (adjusted): 19712017

Included observations: 47 after adjustments

$\begin{array}{llll}\text { Variable } & \text { Coefficient } & \text { Std. Error } & \text { t-Statistic }\end{array}$




\begin{tabular}{|c|c|c|c|c|}
\hline $\operatorname{LOG}(\operatorname{EXR}(-1))$ & -0.117854 & 0.062536 & -1.884574 & 0.0661 \\
\hline $\mathrm{C}$ & -0.088481 & 0.126097 & -0.701694 & 0.4866 \\
\hline @TREND(“1970”) & 0.021258 & 0.010781 & 1.971847 & 0.0549 \\
\hline R-squared & 0.081232 & \multicolumn{2}{|c|}{ Mean dependent var } & 0.134535 \\
\hline Adjusted R-squared & 0.039470 & \multicolumn{2}{|c|}{ S.D. dependent var } & 0.279253 \\
\hline S.E. of regression & 0.273686 & \multicolumn{2}{|c|}{ Akaike info criterion } & 0.308032 \\
\hline Sum squared resid & 3.295782 & \multicolumn{2}{|c|}{ Schwarz criterion } & 0.426127 \\
\hline Log likelihood & -4.238762 & \multicolumn{2}{|c|}{ Hannan-Quinn criter. } & 0.352472 \\
\hline F-statistic & 1.945119 & \multicolumn{2}{|c|}{ Durbin-Watson stat } & 1.598006 \\
\hline Prob(F-statistic) & 0.155069 & & & \\
\hline
\end{tabular}

Null Hypothesis: $\mathrm{D}(\mathrm{LOG}(\mathrm{EXR}))$ has a unit root

Exogenous: Constant, Linear Trend

Lag Length: 0 (Automatic - based on SIC, maxlag=9)

\begin{tabular}{llll}
\hline \hline & & t-Statistic & Prob. $^{\star}$ \\
\hline \hline Augmented Dickey-Fuller test statistic & & -5.534373 & 0.0002 \\
\hline Test critical values: & $1 \%$ level & -4.170583 & \\
& $5 \%$ level & -3.510740 & \\
& $10 \%$ level & -3.185512 & \\
\hline \hline
\end{tabular}

*MacKinnon (1996) one-sided p-values.

Augmented Dickey-Fuller Test Equation

Dependent Variable: D(LOG(EXR),2)

Method: Least Squares

Date: 03/18/19 Time: 08:49

Sample (adjusted): 19722017

Included observations: 46 after adjustments

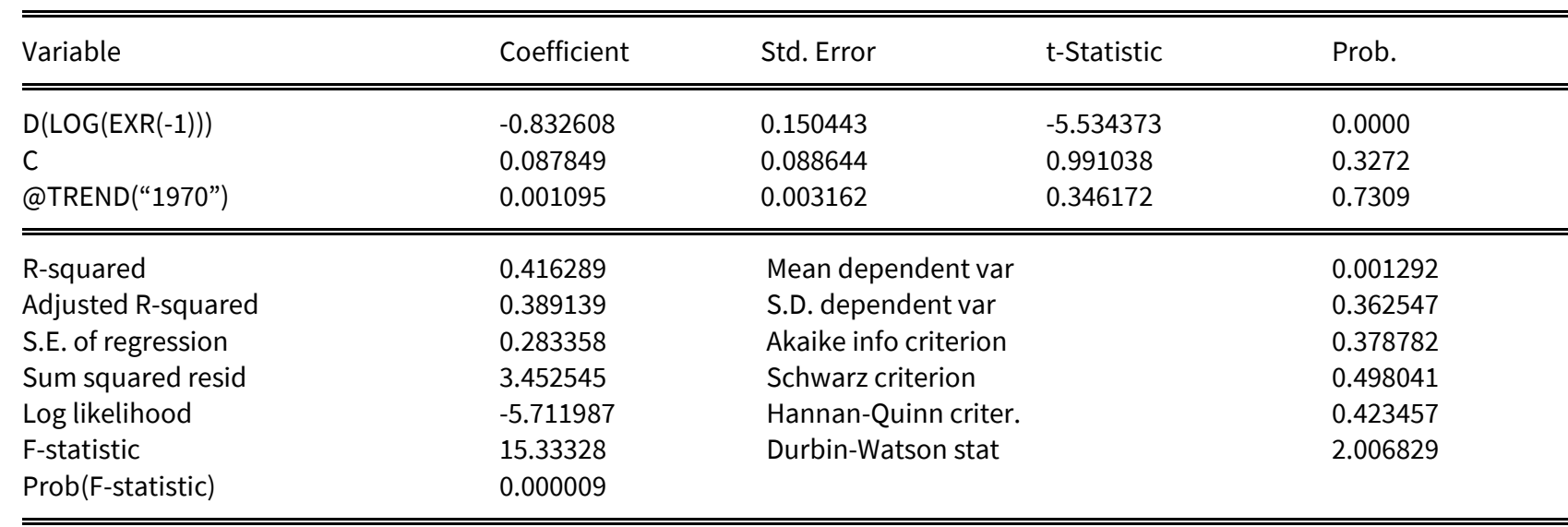

Null Hypothesis: LOG(INFS) has a unit root

Exogenous: Constant, Linear Trend

Lag Length: 0 (Automatic - based on SIC, maxlag=9)

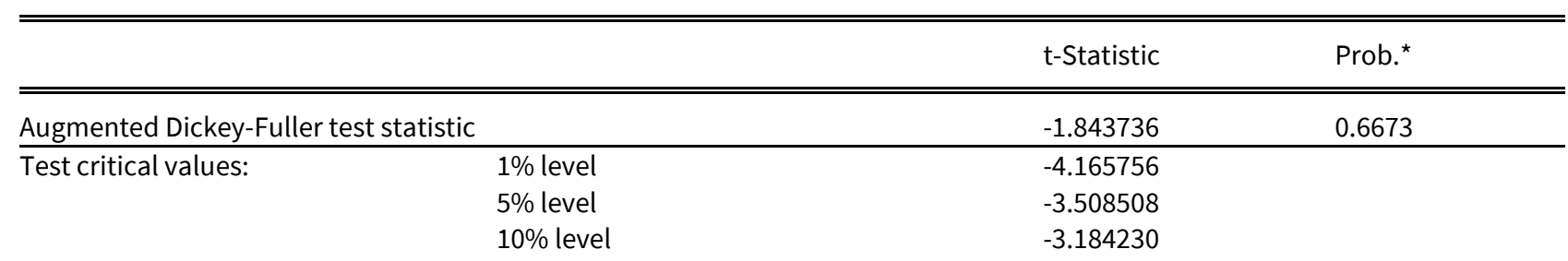


*MacKinnon (1996) one-sided p-values.

Augmented Dickey-Fuller Test Equation

Dependent Variable: D(LOG(INFS))

Method: Least Squares

Date: 03/18/19 Time: 08:49

Sample (adjusted): 19712017

Included observations: 47 after adjustments

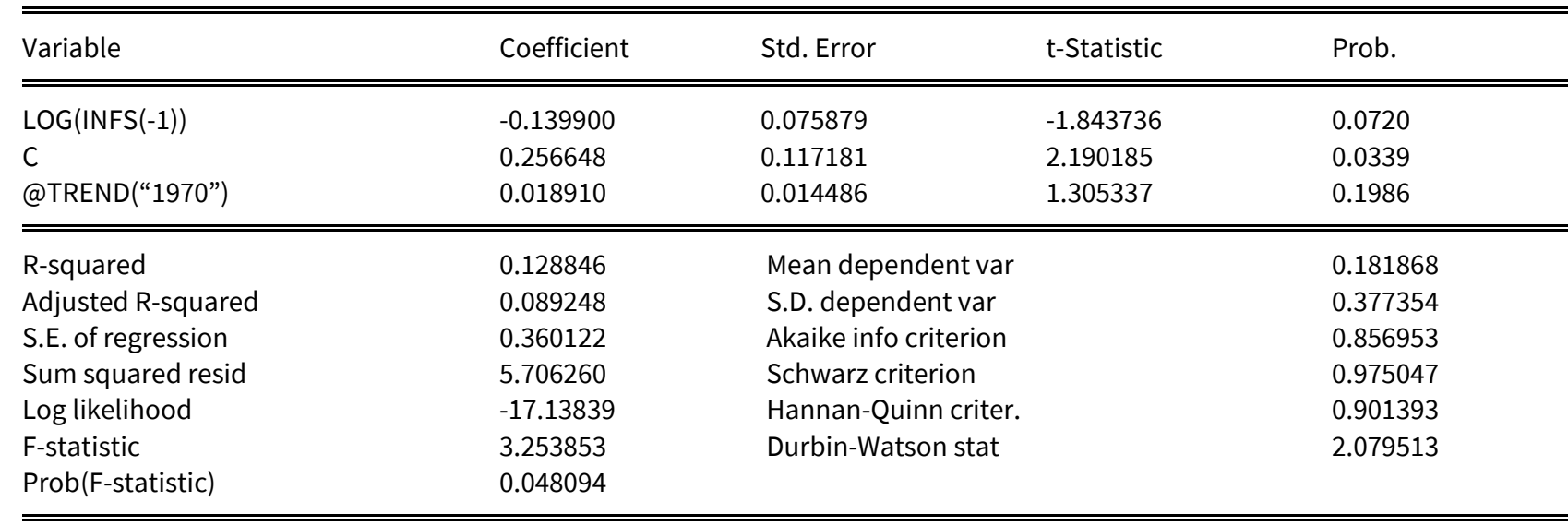

Null Hypothesis: D(LOG(INFS)) has a unit root

Exogenous: Constant, Linear Trend

Lag Length: 0 (Automatic - based on SIC, maxlag=9)

\begin{tabular}{llll}
\hline \hline & & t-Statistic & Prob. $^{*}$ \\
\hline \hline Augmented Dickey-Fuller test statistic & $1 \%$ level & -7.623327 & 0.0000 \\
\hline Test critical values: & $5 \%$ level & -4.170583 & \\
& $10 \%$ level & -3.510740 & \\
& & -3.185512 & \\
\hline \hline
\end{tabular}

*MacKinnon (1996) one-sided p-values.

Augmented Dickey-Fuller Test Equation

Dependent Variable: D(LOG(INFS),2)

Method: Least Squares

Date: 03/18/19 Time: 08:50

Sample (adjusted): 19722017

Included observations: 46 after adjustments

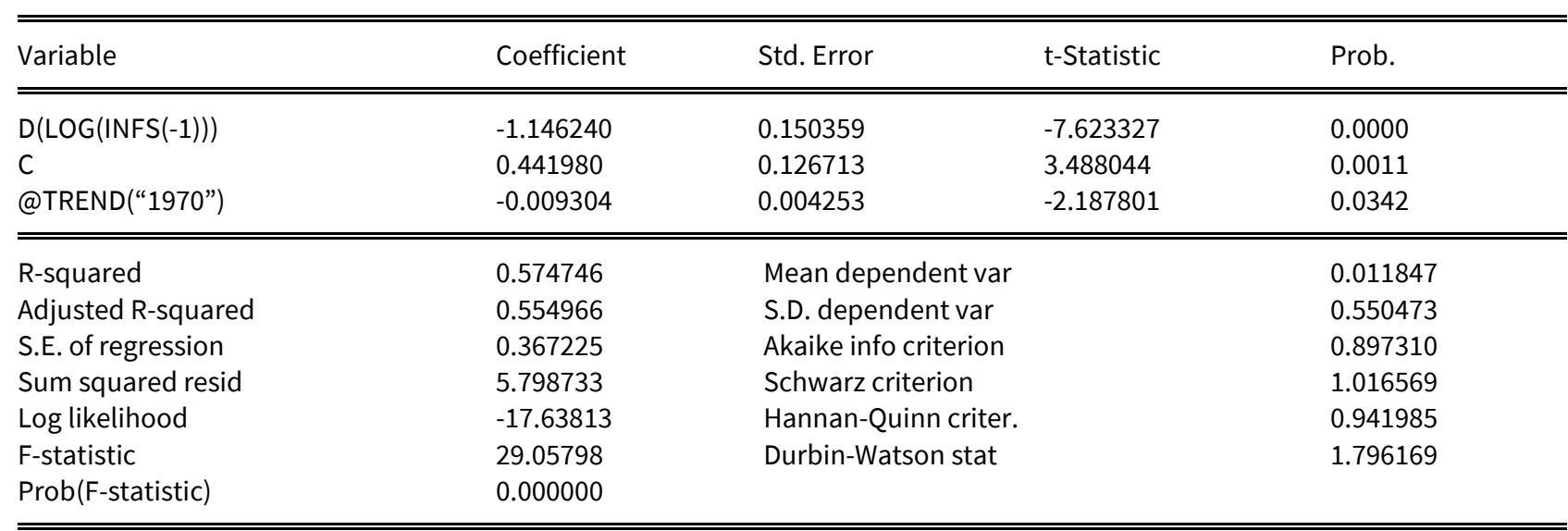




\section{Cointegration Results}

ARDL Bounds Test

Date: 03/31/19 Time: 08:23

Sample: 19712017

Included observations: 47

Null Hypothesis: No long-run relationships exist

\begin{tabular}{lll}
\hline \hline Test Statistic & Value & $\mathrm{K}$ \\
\hline \hline F-statistic & 4.920263 & 4 \\
\hline \hline
\end{tabular}

Critical Value Bounds

\begin{tabular}{lll}
\hline \hline Significance & I0 Bound & I1 Bound \\
\hline \hline $10 \%$ & 2.45 & 3.52 \\
$5 \%$ & 2.86 & 4.01 \\
$2.5 \%$ & 3.25 & 4.49 \\
$1 \%$ & 3.74 & 5.06 \\
\hline \hline
\end{tabular}

Test Equation:

Dependent Variable: DLOG(MSQ)

Method: Least Squares

Date: 03/31/19 Time: 08:23

Sample: 19712017

Included observations: 47

\begin{tabular}{|c|c|c|c|c|}
\hline Variable & Coefficient & Std. Error & t-Statistic & Prob. \\
\hline LOG(INFS) & -0.242741 & 0.131935 & -1.839857 & 0.0732 \\
\hline $\mathrm{C}$ & -0.079134 & 0.225066 & -0.351605 & 0.7270 \\
\hline LOG(PDI(-1)) & 0.640710 & 0.193360 & 3.313556 & 0.0020 \\
\hline INF & 0.004544 & 0.005371 & 0.846110 & 0.4025 \\
\hline $\operatorname{ITR}(-1)$ & 0.001103 & 0.005559 & 0.198385 & 0.8437 \\
\hline LOG(EXR(-1)) & -0.345357 & 0.141004 & -2.449267 & 0.0188 \\
\hline LOG(MSQ(-1)) & -0.373558 & 0.107033 & -3.490129 & 0.0012 \\
\hline R-squared & 0.268906 & \multicolumn{2}{|c|}{ Mean dependent var } & 0.184067 \\
\hline Adjusted R-squared & 0.159242 & \multicolumn{2}{|c|}{ S.D. dependent var } & 0.559272 \\
\hline S.E. of regression & 0.512813 & \multicolumn{2}{|c|}{ Akaike info criterion } & 1.638792 \\
\hline Sum squared resid & 10.51907 & \multicolumn{2}{|c|}{ Schwarz criterion } & 1.914346 \\
\hline Log likelihood & -31.51161 & \multicolumn{2}{|c|}{ Hannan-Quinn criter. } & 1.742485 \\
\hline F-statistic & 2.452091 & \multicolumn{2}{|c|}{ Durbin-Watson stat } & 1.801667 \\
\hline Prob(F-statistic) & 0.041037 & & & \\
\hline
\end{tabular}

Dependent Variable: LOG(MSQ)

Method: ARDL

Date: 03/31/19 Time: 08:21

Sample (adjusted): 19712017

Included observations: 47 after adjustments

Maximum dependent lags: 4 (Automatic selection)

Model selection method: Akaike info criterion (AIC)

Dynamic regressors (4 lags, automatic): LOG(PDI) INF ITR LOG(EXR)

Fixed regressors: LOG(INFS) C

Number of models evalulated: 2500

Selected Model: ARDL $(1,0,0,0,0)$

Note: final equation sample is larger than selection sample

\begin{tabular}{lcccc}
\hline \hline Variable & Coefficient & Std. Error & t-Statistic & Prob.* $^{*}$ \\
\hline \hline LOG(MSQ(-1)) & 0.750909 & 0.077304 & 9.713775 & 0.0000 \\
LOG(PDI) & 0.482340 & 0.147014 & 3.280918 & 0.0022
\end{tabular}




\begin{tabular}{|c|c|c|c|c|}
\hline INF & 0.007460 & 0.004777 & 1.561554 & 0.1263 \\
\hline ITR & -0.021369 & 0.004918 & -4.345105 & 0.0001 \\
\hline LOG(EXR) & -0.257908 & 0.109476 & -2.355837 & 0.0235 \\
\hline LOG(INFS) & 0.166583 & 0.114996 & 1.448598 & 0.1552 \\
\hline $\mathrm{C}$ & -0.073406 & 0.187834 & -0.390804 & 0.6980 \\
\hline R-squared & 0.968812 & \multicolumn{2}{|c|}{ Mean dependent var } & 2.961708 \\
\hline Adjusted R-squared & 0.964134 & \multicolumn{2}{|c|}{ S.D. dependent var } & 2.286366 \\
\hline S.E. of regression & 0.432998 & \multicolumn{2}{|c|}{ Akaike info criterion } & 1.300437 \\
\hline Sum squared resid & 7.499492 & \multicolumn{2}{|c|}{ Schwarz criterion } & 1.575991 \\
\hline Log likelihood & -23.56027 & \multicolumn{2}{|c|}{ Hannan-Quinn criter. } & 1.404130 \\
\hline F-statistic & 207.0932 & \multicolumn{2}{|c|}{ Durbin-Watson stat } & 1.849734 \\
\hline Prob(F-statistic) & 0.000000 & & & \\
\hline
\end{tabular}

*Note: p-values and any subsequent tests do not account for model selection.

ARDL Cointegrating And Long Run Form

Dependent Variable: LOG(MSQ)

Selected Model: ARDL(1, 0, 0, 0, 0)

Date: 03/31/19 Time: 09:41

Sample: 19702017

Included observations: 47

\begin{tabular}{|c|c|c|c|c|}
\hline \multicolumn{5}{|c|}{ Cointegrating Form } \\
\hline Variable & Coefficient & Std. Error & t-Statistic & Prob. \\
\hline DLOG(PDI) & 0.482340 & 0.147014 & 3.280918 & 0.0022 \\
\hline $\mathrm{D}(\mathrm{INF})$ & 0.007460 & 0.004777 & 1.561554 & 0.1263 \\
\hline $\mathrm{D}(\mathrm{ITR})$ & -0.021369 & 0.004918 & -4.345105 & 0.0001 \\
\hline DLOG(EXR) & -0.257908 & 0.109476 & -2.355837 & 0.0235 \\
\hline DLOG(INFS) & 0.166583 & 0.114996 & 1.448598 & 0.1552 \\
\hline CointEq(-1) & -0.249091 & 0.077304 & -3.222246 & 0.0025 \\
\hline
\end{tabular}

Cointeq $=$ LOG(MSQ) $-\left(1.9364^{\star}\right.$ LOG(PDI) $-0.0300^{\star} I N F-0.0858^{\star}$ ITR $-1.0354^{\star}$ LOG(EXR) $+0.6688^{\star}$ LOG(INFS) -0.2947 )

Long Run Coefficients

\begin{tabular}{|c|c|c|c|c|}
\hline Variable & Coefficient & Std. Error & t-Statistic & Prob. \\
\hline LOG(PDI) & 1.936400 & 0.372461 & 5.198931 & 0.0000 \\
\hline INF & 0.029950 & 0.023709 & 1.263230 & 0.2138 \\
\hline ITR & -0.085789 & 0.035408 & -2.422858 & 0.0200 \\
\hline LOG(EXR) & -1.035398 & 0.406976 & -2.544127 & 0.0149 \\
\hline LOG(INFS) & 0.668765 & 0.401575 & 2.624892 & 0.0120 \\
\hline $\mathrm{C}$ & -0.294696 & 0.729871 & -0.403764 & 0.6885 \\
\hline
\end{tabular}

Breusch-Godfrey Serial Correlation LM Test:

\begin{tabular}{|c|c|c|c|}
\hline F-statistic & 1.493070 & Prob. $F(2,38)$ & 0.2376 \\
\hline Obs ${ }^{\star} \mathrm{R}$-squared & 3.424293 & Prob. Chi-Square(2) & 0.1805 \\
\hline
\end{tabular}

Test Equation:

Dependent Variable: RESID 
Method: ARDL

Date: 03/31/19 Time: 09:36

Sample: 19712017

Included observations: 47

Presample missing value lagged residuals set to zero.

\begin{tabular}{|c|c|c|c|c|}
\hline Variable & Coefficient & Std. Error & t-Statistic & Prob. \\
\hline LOG(MSQ $(-1))$ & 0.038458 & 0.095437 & 0.402964 & 0.6892 \\
\hline LOG(PDI) & -0.052802 & 0.169017 & -0.312405 & 0.7564 \\
\hline INF & 0.000499 & 0.004823 & 0.103491 & 0.9181 \\
\hline ITR & 0.000203 & 0.004946 & 0.041026 & 0.9675 \\
\hline LOG(EXR) & 0.030480 & 0.117249 & 0.259957 & 0.7963 \\
\hline LOG(INFS) & 0.011718 & 0.117472 & 0.099754 & 0.9211 \\
\hline $\mathrm{C}$ & 0.019618 & 0.191706 & 0.102334 & 0.9190 \\
\hline RESID(-1) & 0.052924 & 0.183408 & 0.288557 & 0.7745 \\
\hline $\operatorname{RESID}(-2)$ & -0.285349 & 0.173277 & -1.646776 & 0.1079 \\
\hline R-squared & 0.072857 & \multicolumn{2}{|c|}{ Mean dependent var } & $-1.25 \mathrm{E}-15$ \\
\hline Adjusted R-squared & -0.122331 & \multicolumn{2}{|c|}{ S.D. dependent var } & 0.403773 \\
\hline S.E. of regression & 0.427757 & \multicolumn{2}{|c|}{ Akaike info criterion } & 1.309896 \\
\hline Sum squared resid & 6.953099 & \multicolumn{2}{|c|}{ Schwarz criterion } & 1.664179 \\
\hline Log likelihood & -21.78255 & \multicolumn{2}{|c|}{ Hannan-Quinn criter. } & 1.443215 \\
\hline F-statistic & 0.373267 & \multicolumn{2}{|c|}{ Durbin-Watson stat } & 2.010489 \\
\hline Prob(F-statistic) & 0.928222 & & & \\
\hline
\end{tabular}

Heteroskedasticity Test: Harvey

\begin{tabular}{llll}
\hline \hline F-statistic & 2.277378 & Prob. F(6,40) & 0.1552 \\
Obs ${ }^{\star}$ R-squared & 11.96738 & Prob. Chi-Square(6) & 0.1627 \\
Scaled explained SS & 13.35802 & Prob. Chi-Square(6) & 0.2377 \\
\hline \hline
\end{tabular}

Test Equation:

Dependent Variable: LRESID2

Method: Least Squares

Date: 03/31/19 Time: 09:37

Sample: 19712017

Included observations: 47

\begin{tabular}{|c|c|c|c|c|}
\hline Variable & Coefficient & Std. Error & t-Statistic & Prob. \\
\hline $\mathrm{C}$ & -5.153473 & 0.952797 & -5.408784 & 0.0000 \\
\hline LOG(MSQ(-1)) & -0.919264 & 0.392126 & -2.344306 & 0.0241 \\
\hline LOG(PDI) & 1.132664 & 0.745735 & 1.518855 & 0.1367 \\
\hline INF & 0.008134 & 0.024234 & 0.335660 & 0.7389 \\
\hline ITR & -0.042645 & 0.024947 & -1.709445 & 0.0951 \\
\hline LOG(EXR) & -0.230039 & 0.555324 & -0.414243 & 0.6809 \\
\hline LOG(INFS) & -0.305731 & 0.583325 & -0.524119 & 0.6031 \\
\hline R-squared & 0.254625 & \multicolumn{2}{|c|}{ Mean dependent var } & -3.702203 \\
\hline Adjusted R-squared & 0.142819 & \multicolumn{2}{|c|}{ S.D. dependent var } & 2.372338 \\
\hline S.E. of regression & 2.196407 & \multicolumn{2}{|c|}{ Akaike info criterion } & 4.548127 \\
\hline Sum squared resid & 192.9681 & \multicolumn{2}{|c|}{ Schwarz criterion } & 4.823681 \\
\hline Log likelihood & -99.88098 & \multicolumn{2}{|c|}{ Hannan-Quinn criter. } & 4.651820 \\
\hline F-statistic & 2.277378 & \multicolumn{2}{|c|}{ Durbin-Watson stat } & 1.988832 \\
\hline Prob(F-statistic) & 0.055224 & & & \\
\hline
\end{tabular}


Ramsey RESET Test

Equation: UNTITLED

Specification: LOG(MSQ) LOG(MSQ(-1)) LOG(PDI) INF ITR LOG(EXR)

LOG(INFS) C

Omitted Variables: Squares of fitted values

\begin{tabular}{llll}
\hline \hline & Value & $\mathrm{df}$ & Probability \\
\cline { 2 - 4 } t-statistic & 1.291757 & 39 & 0.2040 \\
F-statistic & 1.668636 & $(1,39)$ & 0.2040 \\
\hline \hline F-test summary: & & & \\
& Sum of Sq. & $\mathrm{df}$ & Mean Squares \\
\cline { 2 - 4 } Test SSR & 0.307704 & 1 & 0.307704 \\
Restricted SSR & 7.499492 & 40 & 0.187487 \\
Unrestricted SSR & 7.191787 & 39 & 0.184405 \\
\hline \hline
\end{tabular}

Unrestricted Test Equation:

Dependent Variable: LOG(MSQ)

Method: ARDL

Date: 03/31/19 Time: 08:27

Sample: 19712017

Included observations: 47

Maximum dependent lags: 4 (Automatic selection)

Model selection method: Akaike info criterion (AIC)

Dynamic regressors (4 lags, automatic):

Fixed regressors: $\mathrm{C}$

\begin{tabular}{|c|c|c|c|c|}
\hline Variable & Coefficient & Std. Error & t-Statistic & Prob.* \\
\hline LOG(MSQ(-1)) & 0.645876 & 0.111754 & 5.779448 & 0.0000 \\
\hline LOG(PDI) & 0.403602 & 0.158029 & 2.553984 & 0.0147 \\
\hline INF & -0.005184 & 0.005055 & -1.025480 & 0.3115 \\
\hline ITR & -0.019481 & 0.005092 & -3.825792 & 0.0005 \\
\hline LOG(EXR) & -0.262062 & 0.108620 & -2.412646 & 0.0206 \\
\hline LOG(INFS) & -0.062062 & 0.139835 & -0.443824 & 0.6596 \\
\hline $\mathrm{C}$ & -0.059585 & 0.186590 & -0.319336 & 0.7512 \\
\hline FITTED $^{\wedge} 2$ & 0.016314 & 0.012630 & 1.291757 & 0.2040 \\
\hline R-squared & 0.970092 & \multicolumn{2}{|c|}{ Mean dependent var } & 2.961708 \\
\hline Adjusted R-squared & 0.964724 & \multicolumn{2}{|c|}{ S.D. dependent var } & 2.286366 \\
\hline S.E. of regression & 0.429424 & \multicolumn{2}{|c|}{ Akaike info criterion } & 1.301095 \\
\hline Sum squared resid & 7.191787 & \multicolumn{2}{|c|}{ Schwarz criterion } & 1.616013 \\
\hline Log likelihood & -22.57573 & \multicolumn{2}{|c|}{ Hannan-Quinn criter. } & 1.419601 \\
\hline F-statistic & 180.7140 & \multicolumn{2}{|c|}{ Durbin-Watson stat } & 1.883062 \\
\hline Prob(F-statistic) & 0.000000 & & & \\
\hline
\end{tabular}

${ }^{*}$ Note: $p$-values and any subsequent tests do not account for model selection. 


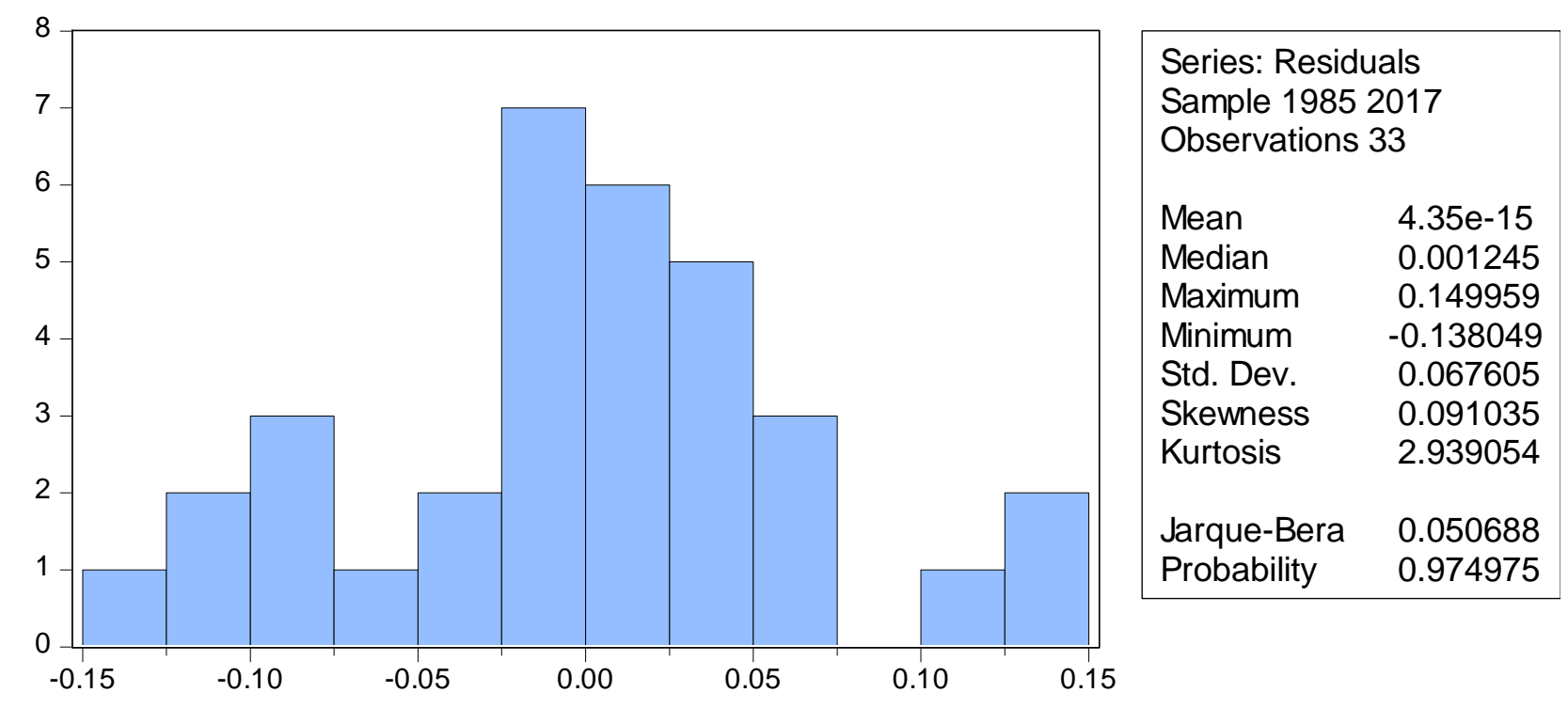

